\title{
Power cycles integration in concentrated solar power plants with energy storage based on calcium looping
}

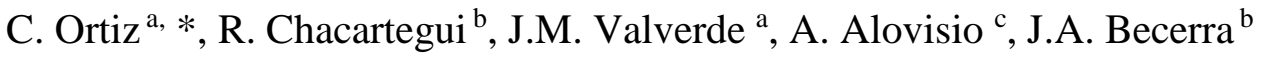 \\ ${ }^{a}$ Faculty of Physics, University of Seville, Avenida Reina Mercedes s/n, 41012 Sevilla, Spain \\ ${ }^{\mathrm{b}}$ Energy Engineering Department, University of Seville, Camino de los Descubrimientos s/n, 41092 Sevilla, Spain \\ c Politecnico di Torino, Department of Energy Engineering, Corso Duca degli Abruzzi 24, 10129 Torino, Italy \\ * Corresponding author. Tel.: +34 655783930 \\ E-mail address: cortiz7@us.es
}

\begin{abstract}
Efficient, low-cost and environmentally friendly storage of thermal energy stands as a main challenge for large scale deployment of solar energy. This work explores the integration into concentrated solar power plants of the calcium looping process based upon the reversible carbonation/calcination of calcium oxide for thermochemical energy storage. An efficient concentrated solar power-calcium looping integration would allow storing energy in the long term by calcination of calcium carbonate thus overcoming the hurdle of variable power generation from Solar. After calcination, the stored products of the reaction (calcium oxide and carbon dioxide) are brought together in a carbonator reactor whereby the high temperature exothermic reaction releases the stored energy for efficient power production when needed. This work analyses several power cycle configurations with the main goal of optimizing the performance of the overall system integration. Possible integration schemes are proposed in which power production is carried out directly (using a closed carbon dioxide Brayton power cycle) or indirectly (by means of a steam reheat Rankine cycle or a supercritical carbon dioxide Brayton cycle). The results obtained show that the highest plant efficiencies (up to 45-46\%) are achievable using a closed carbon dioxide Brayton power cycle.
\end{abstract}

\section{Keywords}

Global warming, Renewable energies, Concentrated Solar Power (CSP), Thermochemical energy storage (TCES), Calcium looping (CaL), Power cycles, Supercritical $\mathrm{CO}_{2}$ power cycle.

\section{Introduction}

The commercial expansion of renewable energy technologies is an urgent need to limit global warming to "well below" $2.0^{\circ} \mathrm{C}$ (by 2100) and pursue $1.5^{\circ} \mathrm{C}$ above pre-industrial levels as was at Paris COP21 Conference [1]. In particular, Concentrated Solar Power (CSP) should play a leading role within the new energy landscape as it lends itself to potentially cheap storage of energy in the form of heat [2]. Thus, efficient and affordable thermal energy storage systems must be developed in order to decouple production and demand [3], which would allow a deep penetration of solar energy power generation into the grid.

In recent years a large number of potential thermal storage technologies for medium to high temperature CSP systems have been proposed [4] based upon three main concepts: i) sensible Thermal Energy Storage (TES), such as direct steam storage [5] or molten salt systems [6,7]; ii) latent heat storage using Phase Change Materials (PCMs), on which Zalba et al. [8] published a comprehensive review of materials and applications; and iii) Thermochemical Energy Storage (TCES). Regarding to TCES, a large number of potential systems [9], experimental research 
under practical conditions [10] and TCES reactor designs [11] can be found in literature. Essentially, TCES consists of using the heat obtained from an external source, such as CSP, to drive an endothermic reaction. When energy is needed, the separately stored by-products of the reaction are brought together at the necessary conditions for the reverse exothermic reaction to occur, which releases the previously used heat for power production. The main advantages of TCES as compared to TES and PCMs are the considerably high energy density attainable, which is well above the energy density of molten salts currently used in commercial plants ( $0.5 \mathrm{GJ} / \mathrm{m}^{3}$ ) [12], and the possibility of storing energy in the long term [9]. An extended review on long-term solar heat storage can be found in ref. [13]. Moreover, in addition to the chemically stored heat, sensible heat stored in the reaction by-products is also usable.

The focus of the present manuscript is on TCES in CSP tower plants. In order to achieve an efficient and cost-effective thermochemical storage process, a proper selection of the reversible reaction is a crucial issue. Among the possibilities explored for TCES in CSP tower plants at large scale, one of the most promising systems is the Calcium Looping $(\mathrm{CaL})$ process, which relies on the carbonation-calcination reaction of calcium oxide $(\mathrm{CaO})(\mathrm{Eq}$. (1)) [14]. The use of several $\mathrm{CaO}$ precursors for TCES in CSP plants has been analysed in [15].

$$
\mathrm{CaO}_{(\mathrm{s})}+\mathrm{CO}_{2(\mathrm{~g})} \rightleftarrows \mathrm{CaCO}_{3(\mathrm{~s})} \quad \Delta \mathrm{H}_{\mathrm{r}}^{0}=-178 \mathrm{~kJ} / \mathrm{mol}
$$

Generally, the $\mathrm{CaL}$ process would begin with the decomposition of calcium carbonate $\left(\mathrm{CaCO}_{3}\right)$ particulate solids in a calcination reactor (calciner) yielding $\mathrm{CaO}$ and $\mathrm{CO}_{2}$ as by-products. A high energy input is necessary to rise the solids stream temperature up to the value required for the reaction to occur at a sufficiently fast rate and to carry out the endothermic calcination reaction [16]. Thus, the optimum calcination temperature is essentially determined by the composition of the gas in the calcination environment [17]. Once the sensible heat from the calciner outlet streams ( $\mathrm{CaO}$ and $\mathrm{CO}_{2}$ streams) is recovered, these products are separately stored. Storage conditions and time are flexible and could be accommodated to energy demand and environmental circumstances. When needed, the $\mathrm{CaO}$ and $\mathrm{CO}_{2}$ products are circulated into a carbonator reactor, where energy is recovered from the carbonation reaction.

A great benefit of the CaL process is the low price ( $10 \$ /$ ton), wide availability and harmlessness towards the environment of natural limestone and dolomites to be used as $\mathrm{CaO}$ precursor [18]. However, a usually claimed drawback of the CaL process is the marked deactivation of $\mathrm{CaO}$ derived from these natural minerals with the number of carbonation/calcination cycles. $\mathrm{CaO}$ deactivation is indeed particularly relevant when the $\mathrm{CaL}$ process is used for $\mathrm{CO}_{2}$ capture $[19,20]$ under conditions that necessary involve regeneration of $\mathrm{CaO}$ by high temperature (around $950^{\circ} \mathrm{C}$ ) calcination at high $\mathrm{CO}_{2}$ partial pressure and carbonation at low $\mathrm{CO}_{2}$ partial pressure $(\sim 0.15$ bar). Nevertheless, $\mathrm{CaL}$ conditions to achieve a high global efficiency for TCES and electricity generation in CSP plants are radically different to those corresponding to its application for $\mathrm{CO}_{2}$ capture [21]. In the CSP-CaL integration, carbonation would be carried out under high $\mathrm{CO}_{2}$ partial pressure and high temperature (around or above $850^{\circ} \mathrm{C}$ ) whereas calcination would be ideally performed at relatively low temperature $\left(\sim 700^{\circ} \mathrm{C}\right)$ under a gas easily separable from $\mathrm{CO}_{2}$ such as Helium [17] or superheated steam [22]. Under these conditions, $\mathrm{CaO}$ derived from natural limestone and dolomite may exhibit a high value of the residual conversion [21].

In addition to enhancing solar energy storage capacity, advanced high efficiency CSP-TESpower cycle integrations should be developed exploiting energy storage conditions to achieve 
a significant improvement of CSP plant performance. Integration of power cycles in commercial CSP tower plants with thermal storage in the form of sensible heat using molten salts is limited by a maximum temperature achievable around $550-600^{\circ} \mathrm{C}$. This limitation is mainly imposed by the degradation of molten salts at higher temperatures [6,7]. In recent years, molten alkali carbonates salts (MACs) have been investigated for energy storage. According to Frangini et al. [23], temperature stability of additives limits the applicability of oxidizing MAC salts at temperatures below $650{ }^{\circ} \mathrm{C}$. On the other hand, thermal radiation losses at the open focal point [24] adds a further temperature limitation in currently CSP plants. This implies that most of the commercial CSP tower plants currently under operation are based in Rankine cycle process [25,26]. Peak solar to electricity conversion efficiencies in these commercial CSP tower plants are around $25-30 \%$, with an annual solar-to-electricity conversion efficiency lower than $20 \%$ [27]. At this regard, Liu et al. [28] presents current annual efficiencies as a function of solar technology used: $13-15 \%$ for parabolic trough, 14-18\% for tower ad 9-13\% for Fresnel. On the other hand, the European Academies Scientific Advisory Council [29] shows the difference of annual solar to electricity efficiencies between conceptual (around 22-28\%) and industrial (around 14-18\%) status.

This manuscript analyses several integration schemes to use the CaL process for TCES in CSP plants. Integration models aimed at similar goals have been already investigated by other authors. Tregambi et al. [30] proposed a scheme whereby calcination in the CaL process is assisted by CSP for $\mathrm{CO}_{2}$ capture in a coal fired power plant. Edwards et al. [31] investigated a CSP-CaL integration in which the heat produced in the carbonator reactor is used for power generation through a $\mathrm{CO}_{2}$ /air open cycle. This configuration assumes that the $\mathrm{CO}_{2}$ stream entering into the carbonator reacts completely with the $\mathrm{CaO}$ solids to produce $\mathrm{CaCO}_{3}$. However, attending to the reaction equilibrium, carbonation will be ceased when the $\mathrm{CO}_{2}$ partial pressure in the carbonator reactor reaches the equilibrium partial pressure (see Equation 8). Thus, $\mathrm{CO}_{2}$ in the carbonator effluent gas will be unavoidably released to the environment in a $\mathrm{CO}_{2} /$ air open cycle at a concentration depending on the carbonator temperature. In order to guarantee the absence of $\mathrm{CO}_{2}$ emissions, alternative power cycles must be employed. In this regard, Chacartegui et al. [32] have recently proposed a CSP-CaL integration wherein the TCES system is integrated with a closed $\mathrm{CO}_{2}$ power cycle directly coupled to the carbonator following a pinch-analysis methodology [33]. In the discharge operation the circulating $\mathrm{CO}_{2}$ passes directly to the carbonator and power turbine. The present manuscript explores the integration with the TCES core system of alternative direct and indirect cycles (steam turbine, closed Brayton $\mathrm{CO}_{2}$ and indirect-supercritical $\mathrm{CO}_{2}$ ) for relevant CSP-CaL integration conditions. The obtained results show that the highest efficiencies are achieved using direct cycles, potentially reaching global power efficiencies above $44 \%$.

\section{CSP-CaL integration model}

In this section the main aspects of the CSP-CaL integration model based on mass and energy balance in heat exchangers, solid reservoirs, $\mathrm{CO}_{2}$ storage tank and reactors are summarized. The interested reader is referred to [32] where the model is described in detail. Moreover, the main CSP-CaL model simulation results are analysed as a previous step to discuss the power cycle integration.

\subsection{Model description}


Figure 1 shows a schematic representation of the CSP-CaL integration model. The process starts in the solar receiver, where solar energy input is used to carry out the calcination of $\mathrm{CaCO}_{3}$ (endothermic reaction). Currently commercial CSP tower systems would allow achieving temperatures in the range of $700-900^{\circ} \mathrm{C}$, which are high enough to drive limestone calcination in short residence times [21] using a solar calciner reactor among those already proposed in the literature [34]. Thus, Meier et al. [35] have developed a solar multi-tube rotary kiln prototype for carrying out the calcination reaction at temperatures up to $1100^{\circ} \mathrm{C}$. Once calcination takes place, the released $\mathrm{CO}_{2}$ is sent to a storage tank after being cooled and compressed whereas the $\mathrm{CaO}$ stream is transported to a solids reservoir. Both streams exiting the calciner at high temperature are passed through a heat exchanger network to extract their sensible heat as a previous step to storage at ambient temperature. This is a main advantage of the CSP-CaL integration over current state of the art sensible heat storage using molten salts, whose temperature must be kept above $\sim 200^{\circ} \mathrm{C}$ to avoid solidification [36]. In order to use reasonably sized $\mathrm{CO}_{2}$ storage volumes a minimum pressure of 75 bar is needed to store $\mathrm{CO}_{2}$ storage under supercritical conditions (considering storage at ambient temperature) [32]. The high compression ratio from calciner to storage conditions (1:75) requires the use of intercooling compression to minimize the efficiency penalty. Solids transport can be carried out by means of pneumatic conveying, an already mature technology to transport high temperature granular solids [37]. For Ca based particles and a typical transport length of $200 \mathrm{~m}$, an energy consumption of $20 \mathrm{MJ} /$ ton has been used in the CSP-CaL integration model [32].

When power is needed the energy stored is released in the carbonator through the exothermic carbonation reaction. According to thermodynamic reaction equilibrium carbonation can be carried out at high temperature $\left(>850^{\circ} \mathrm{C}\right)$ under high $\mathrm{CO}_{2}$ partial pressure [38]. This would allow a highly efficient generation of electricity thus overcoming temperature limits $\left(\mathrm{T} \sim 550-600^{\circ} \mathrm{C}\right)$ in currently commercial CSP plants with thermal storage in molten salts. Solids exiting the carbonator are passed through another heat exchanger network to preheat the $\mathrm{CaO}$ and $\mathrm{CO}_{2}$ streams entering the carbonator. After the storage step, the $\mathrm{CO}_{2}$ stream is expanded to the selected carbonator pressure, which must be below the storage pressure in order to use the commercial fluidized bed technology. As can be seen in Figure 1, compression-expansion process of $\mathrm{CO}_{2}$ before and after the storage step resembles a compressed air energy storage (CAES) system [4]. Thus, besides of sensible and thermochemical energy storage, the integration compresses orates energy storage also in the form of compressed gas with a round trip efficiency of about $67 \%$ using a compression-expansion train (see [32] for further details).

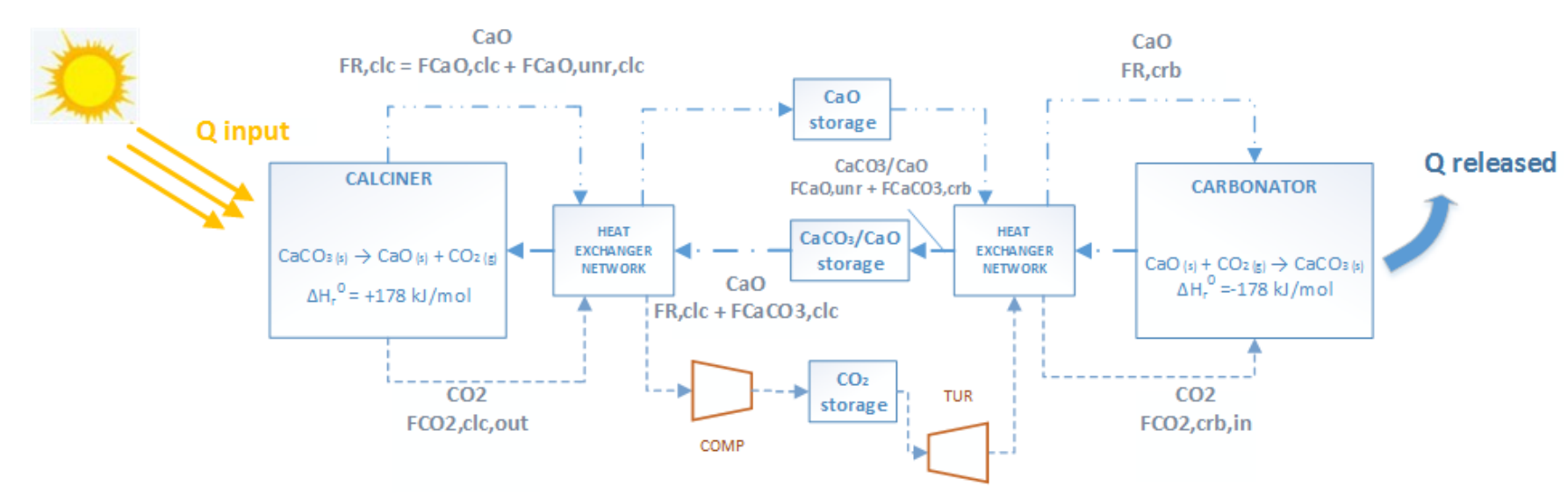




$$
\xi \Delta H_{R}\left(T_{\text {react }}\right)+\sum_{i} F_{i, i n}\left(h_{i, \text { react }}-h_{i, i n}\right)=\Phi-\dot{W}
$$

207 with

$$
\Delta H_{R}\left(T_{\text {react }}\right)=\sum_{i} v_{i} h_{i, T}=\Delta H_{R}^{0}+\sum_{i} v_{i} \int_{\text {ref }}^{T_{\text {react }}} c_{p, i} d T
$$


The proposed CSP-CaL integration model has been simulated to assess the integration efficiency. A sensitivity analysis has been carried out on relevant $\mathrm{CaL}$ cycle parameters such as $\mathrm{CaO}$ average conversion $\mathrm{X}$ and carbonation equilibrium conditions [39]. Data used for the reference case are reported in Table 1.

$\mathrm{CaO}$ average conversion has a significant influence on the solids flow rates, storage vessels, power production and consumption, and heat exchangers network configuration. Thus, a high $\mathrm{CaO}$ conversion leads to a low fraction of unreacted $\mathrm{CaO}$ left, which affects relevantly the plant's performance. As the average $\mathrm{CaO}$ conversion increases the solids mass flow rate is

\begin{tabular}{lrl} 
Net absorbed solar heat flux in calciner & 100 & $\mathrm{MWt}$ \\
\hline Thermal dispersions in carbonator & 10 & $\%$ \\
\hline Calciner temperature & 900 & ${ }^{\circ} \mathrm{C}$ \\
\hline Calciner pressure & 1 & $\mathrm{bar}$ \\
\hline Ambient temperature & 20 & ${ }^{\circ} \mathrm{C}$ \\
\hline $\mathrm{CaO}$ average conversion $(\mathrm{X})$ & 0.5 & \\
\hline Carbonator temperature & 875 & ${ }^{\circ} \mathrm{C}$ \\
\hline Carbonator pressure & 7 & $\mathrm{bar}$ \\
\hline $\mathrm{CO}_{2}$ storage conditions & 75 & $\mathrm{bar}, \mathrm{T}$ ambient \\
\hline Solid phase conveying energy consumption & 20 & $\mathrm{MJ} /$ ton \\
\hline Daylight hours (constant solar flux) & $8 \mathrm{~h}$ & \\
\hline Isentropic efficiencies (compression/expansion) & 0.89 &
\end{tabular}
decreased (Figure 2), therefore energy consumption due to solids conveying is reduced.

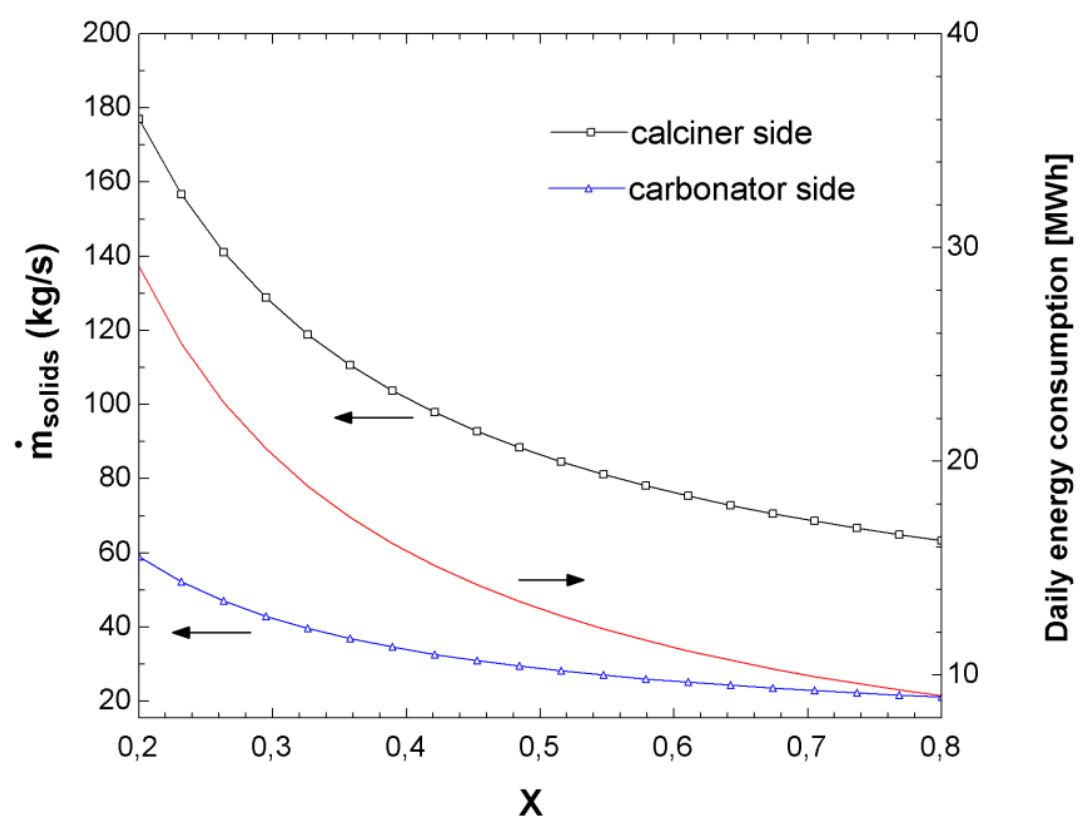

Figure 2: Solids mass flow rate (left axis) and daily energy consumption (right axis) due to solids conveying as a function of average $\mathrm{CaO}$ conversion (X) 
228 Figure 3 shows the effect of the average $\mathrm{CaO}$ conversion on the thermal power effectively used 229 for energy storage. Keeping fixed a $100 \mathrm{MW}_{\text {th }}$ of CSP input $\left(\phi_{C S P}\right)$ into the system, the thermal 230 power used to carry out the calcination reaction $\left(\phi_{\text {calcination }}=92 \mathrm{MWth}\right)$ does not depend on the solids conversion in the carbonator while the rest $(8 \mathrm{MWth})$ is employed to raise the solids temperature before entering into the calciner. A part of the released power in the carbonator $\phi_{\text {released,crb }}$ is used to increase the temperature of the inlet streams up to the carbonation temperature, which leaves the rest of thermal energy available $\phi_{\text {available }}$ to be used in the power cycle for electricity production. The difference between calcination and carbonation power is due to thermal energy dispersions in the carbonator (10\%).

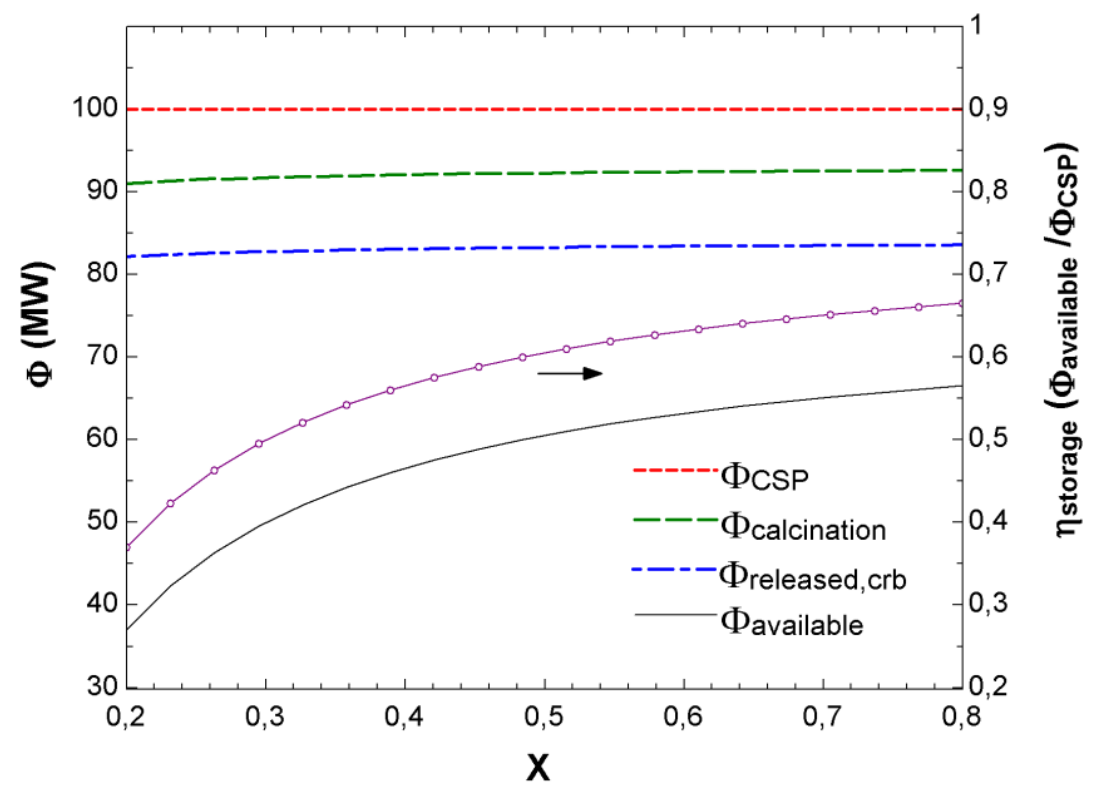

Figure 3: Thermal power fluxes (left axis) and energy storage efficiency (right axis) as a function of average $\mathrm{CaO}$ conversion in the carbonator.

Another relevant issue to be considered is that increasing the average $\mathrm{CaO}$ conversion allows for an important reduction of the solids storage volumes as can be seen in Figure 4a. On the other hand, a change in $X$ does not yield a significant variation of the $\mathrm{CO}_{2}$ storage volume, which is however quite sensitive to $\mathrm{CO}_{2}$ density as determined by storage pressure and temperature (Figure 4b). 

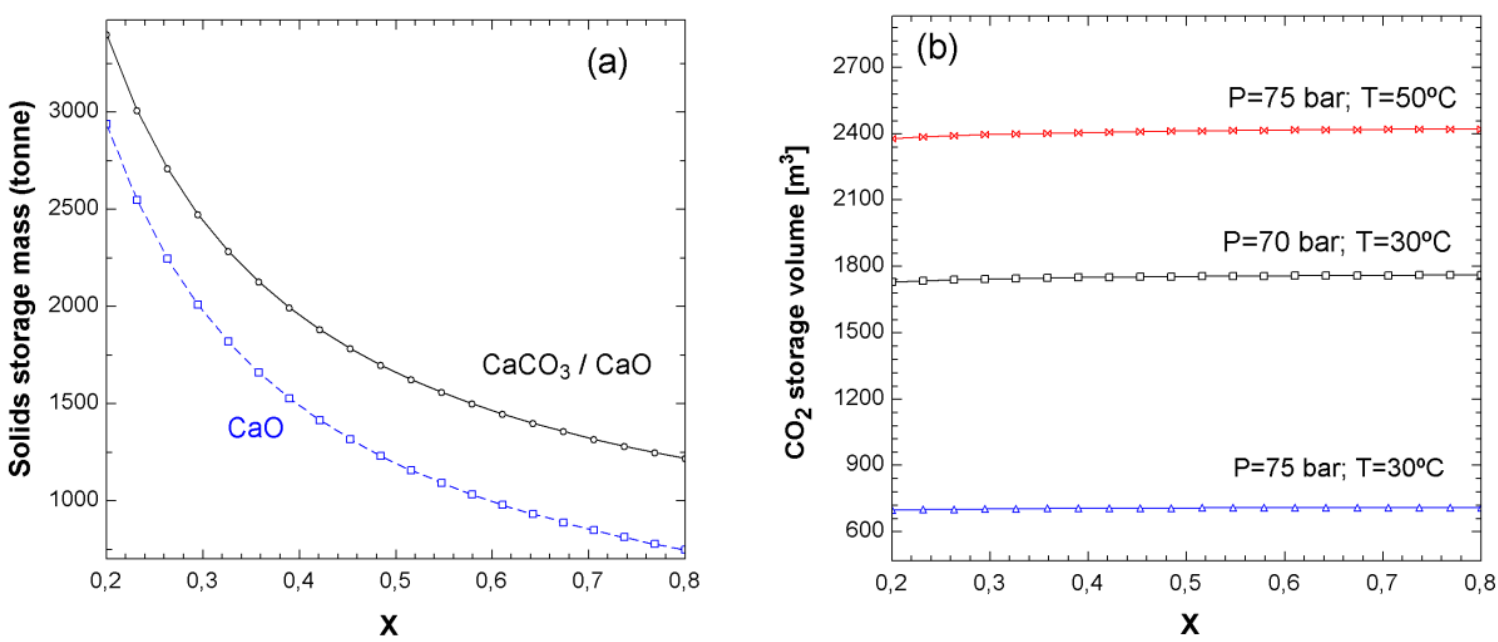

Figure 4: (a) Solids storage mass as a function of average $\mathrm{CaO}$ conversion. (b) $\mathrm{CO}_{2}$ storage volume as a function of average $\mathrm{CaO}$ conversion for several storage conditions.

Previous works on the $\mathrm{CaO}$ multicycle conversion in the $\mathrm{CaL}$ process have been mostly focused on Post-Combustion $\mathrm{CO}_{2}$ Capture (PCCC) conditions, either on laboratory-physical analysis [20,40], reactor modelling [41] or process integration models [42], involving in all cases carbonation under relatively low $\mathrm{CO}_{2}$ partial pressure $(\sim 0.15$ bar $)$ and calcination at very high temperatures $\left(\sim 950^{\circ} \mathrm{C}\right)$ under high $\mathrm{CO}_{2}$ partial pressure. Under these conditions the $\mathrm{CO}_{2}$ sorbent $(\mathrm{CaO})$ presents a severe drop of conversion after a few cycles converging towards a residual value of just about $0.07-0.08$ [43,44]. Nevertheless, it is important to remark that the CSP-CaL integration for thermochemical energy storage involves CaL conditions radically diverse from those in the case of PCCC. Thus, thermogravimetric analysis (TGA) tests show that the residual conversion of limestone derived $\mathrm{CaO}$ can be as large as $X_{r}=0.5$ for conditions that correspond to the optimum CSP-CaL integration that involve carbonation at high temperature under high $\mathrm{CO}_{2}$ partial pressure [21]. Moreover, according to TGA results fast calcination may be achieved at a reduced temperature of just $700-725^{\circ} \mathrm{C}$ under a gas which is easily separable from $\mathrm{CO}_{2}$ (either $\mathrm{He}$ as in the TGA experiments described in [21] or superheated steam [22]). Attaining such a low calcination temperature would allow the use of already mature and inexpensive metallic solar receivers thus reducing technological risks. On the other hand, the work of $\mathrm{He} / \mathrm{CO}_{2}$ or $\mathrm{H}_{2} \mathrm{O} / \mathrm{CO}_{2}$ separation should be also included in an extended techno-economic energy analysis.

Carbonator conditions (pressure and temperature) are highly relevant for the global CSP-CaL power cycle integration. Carbonator pressure is selected by considering the most favorable conditions for the CaL-power cycle integration, i.e. a fluidized bed reactor operated under atmospheric pressure if an indirect power cycle is integrated and a pressurized fluidized bed reactor for direct integration with a power cycle, in order to achieve the higher integration performance. On the other hand, increasing the carbonator temperature $\left(T_{c a r b}\right)$ leads to higher power cycle efficiencies and therefore enhances the CSP-CaL-power cycle integration performance. However, the maximum temperature in the carbonator is limited by the thermodynamic equilibrium of the carbonation/calcination reaction. Thus, for a given $\mathrm{CO}_{2}$ partial pressure in the carbonator there is a maximum carbonator temperature above which the carbonation reaction is not thermodynamically favourable. According to thermochemical data [38], the $\mathrm{CO}_{2}$ partial pressure for the reaction to be at equilibrium at a given temperature $\mathrm{T}(\mathrm{K})$

280 is given by: 


$$
P_{e q}(\text { bar })=P \cdot y_{e q}=\left[4.13710^{7} \exp \left(-\frac{20474}{T}\right)\right]
$$

282

283

In Eq. (8), $y_{e q}$ is the fraction of $\mathrm{CO}_{2}$ in the carbonation environment. For a fixed carbonator temperature, there is a minimum carbonator pressure below which the $\mathrm{CO}_{2}$ partial pressure is insufficient for carbonation to occur. Figure 5 shows the minimum carbonator pressure as a function of reactor temperature to carry out carbonation and for different $\mathrm{CO}_{2}$ fractions (equation (8)). It is clear that operating under pure $\mathrm{CO}_{2}\left(y_{C O 2, \text { in }}=1\right)$ allows working under higher temperatures and low carbonator total pressures.

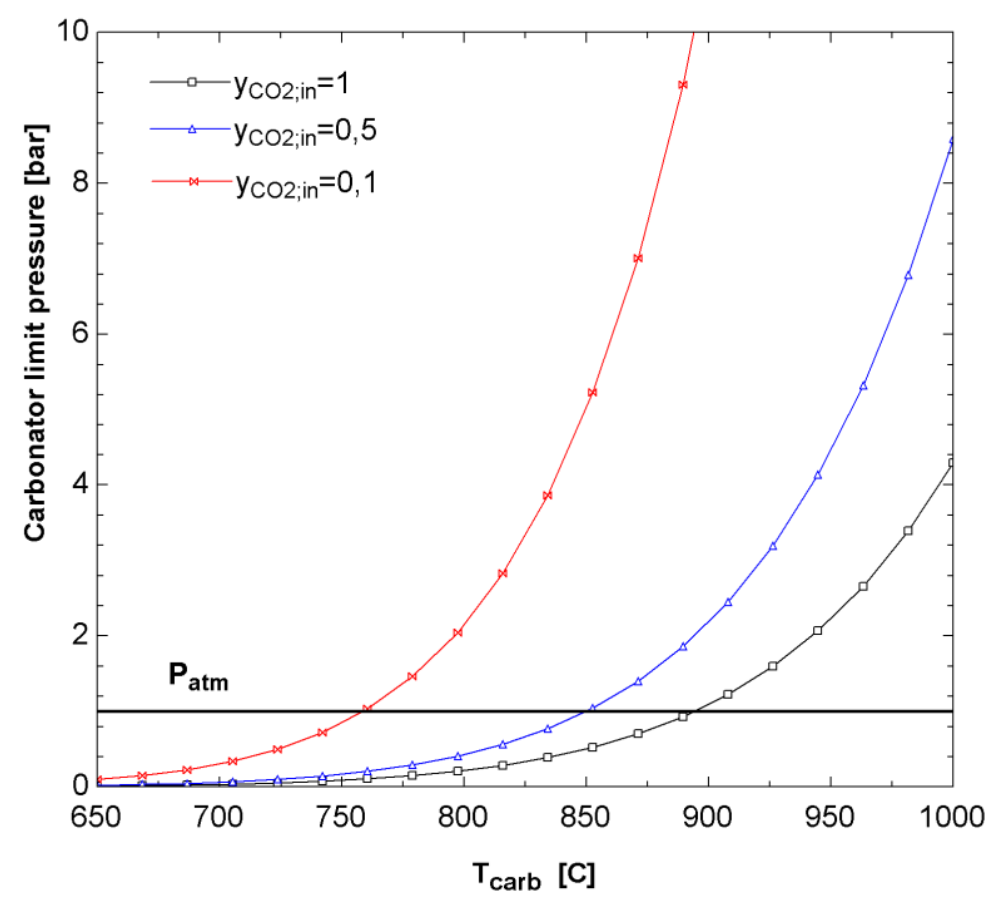

Figure 5: Minimum carbonator pressure as a function of carbonator temperature $T_{\text {carb }}$ for several $\mathrm{CO}_{2}$ volume concentrations at the carbonator inlet ( $\left.\mathrm{y}_{\mathrm{CO} 2, \text { in }}\right)$

\section{CSP-CaL-power cycle integration}

This section is devoted to the study of several power cycle integrations into the CaL based CSP storage system. Power cycles are classified in two categories: power cycles with direct integration $\left(\mathrm{CO}_{2}\right.$ regenerative Brayton cycle) and power cycles with indirect integration (Rankine Reheat cycle and supercritical $\mathrm{CO}_{2}$ recompression cycle).

\subsection{Direct integration}

In power cycles with direct integration the heat transfer fluid used in the carbonator is sent directly into a gas turbine. In the following a $\mathrm{CO}_{2}$ closed Brayton cycle is analysed. 
In this integration scheme (Figure 6), the heat released by the carbonation reaction is delivered to a gas turbine by the excess $\mathrm{CO}_{2}$ that does not participate in the reaction and is used as carrier through a Joule-Brayton cycle. This is therefore a direct integration between the heat released and power cycle, which has been recently studied in [32].

Figure 6 shows the $\mathrm{CO}_{2}$ closed Brayton cycle scheme. The $\mathrm{CO}_{2}$ power cycle is a closed and regenerative cycle, whereby the heat removed by the reactants in the carbonator is recovered in an open cyclone exchanger (HXF in Figure 6). Thus, in this heat exchanger (HXF) heat from the exhaust $\mathrm{CO}_{2}$ stream serves to heat up the $\mathrm{CaO}$ solids before entering the carbonator while in HXE the residual heat from the solids at the carbonator output is extracted to pre-heat the $\mathrm{CO}_{2}$ stream at the carbonator inlet. Part of the power needed in the compression stage of the Joule-Brayton cycle is provided by the expansion of the pressurized $\mathrm{CO}_{2}$ used for reaction in the carbonator. In the $\mathrm{CO}_{2}$ closed configuration the carbonator operates under a $100 \% \mathrm{CO}_{2}$ environment. Therefore, the molar flow rate of $\mathrm{CO}_{2}$ flowing into the carbonator is by large in excess over the stoichiometric need. The $\mathrm{CO}_{2}$ stream in the carbonator side is balanced out to use the non-reacting excess $\mathrm{CO}_{2}$ to deliver heat of the carbonation reaction to the gas turbine for power production. Main data set used in the simulations is shown in Figure 6 as well as results obtained.

The $\mathrm{CO}_{2}$ closed Brayton cycle presents the following characteristics:

- Regarding to chemical equilibrium considerations, by operating in a pure $\mathrm{CO}_{2}$ atmosphere, the minimum carbonator pressure coincides with the $\mathrm{CO}_{2}$ partial pressure, making it possible to attain carbonation temperatures of around $950^{\circ} \mathrm{C}$ for carbonator absolute pressures above 2.2 bar and until around $890^{\circ} \mathrm{C}$ for carbonator pressures above atmospheric pressure (Figure 5).

- $\mathrm{CO}_{2}$ is characterized by lower values of both compression and expansion work compared to air.

- The $\mathrm{CO}_{2}$ Brayton cycle provides a higher useful to expansion work ratio than an air Brayton cycle. Therefore, for a given useful work produced, the $\mathrm{CO}_{2}$ at turbine output presents a higher enthalpy. This is beneficial from the point of view of thermal energy recovery to preheat streams entering into the carbonator (Figure 6), which enhances the plant efficiency.

- Regarding to isentropic efficiency of compressor and turbine, $\mathrm{CO}_{2}$ is less sensitive than air, especially at the compressor [45].

Being a closed cycle, a more flexible operation is possible as compared to open cycles since possible $\mathrm{CO}_{2}$ emissions to the atmosphere are avoided. Thus, the closed Brayton cycle could use a mix of several components as carrier fluid. 


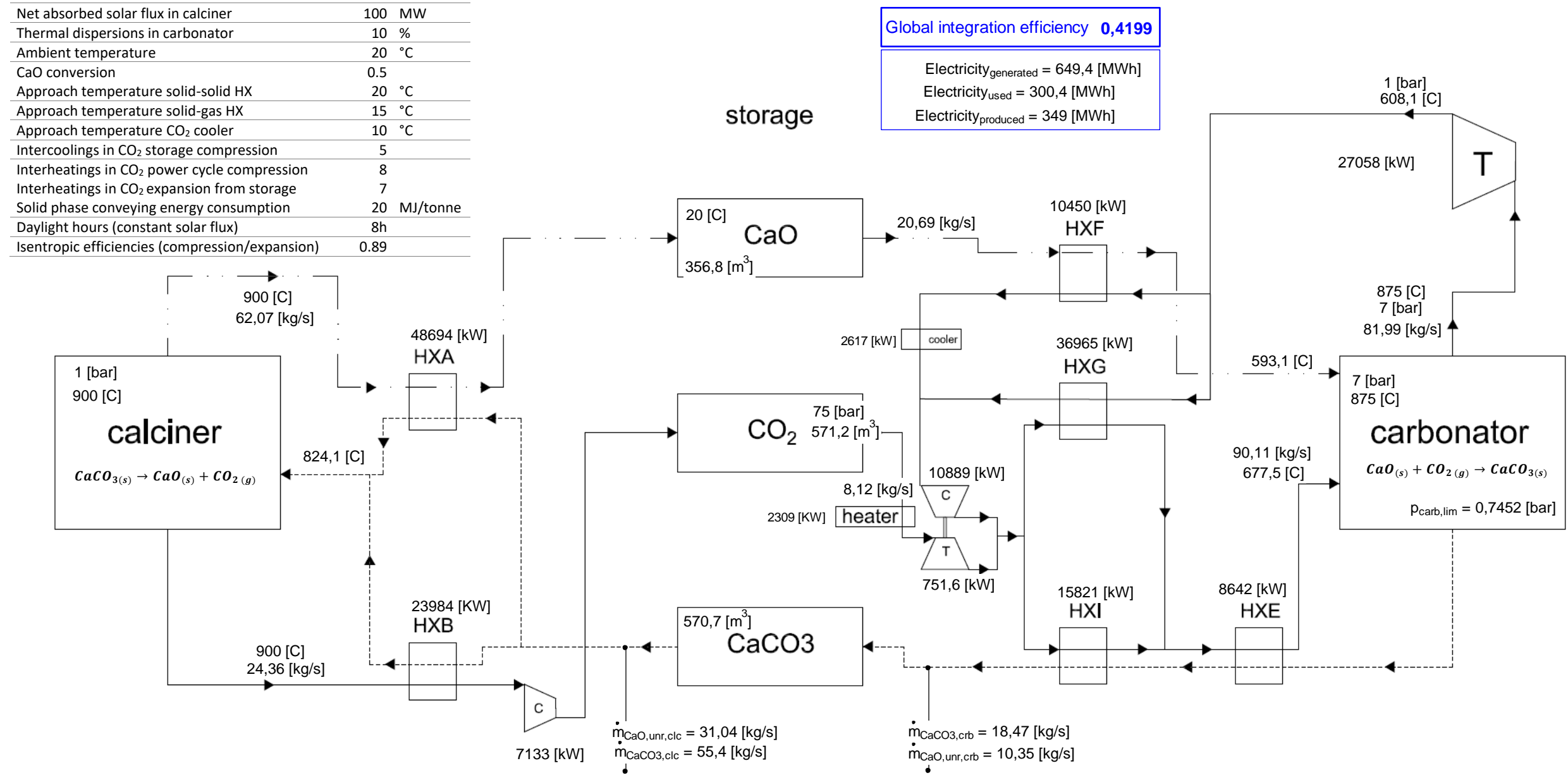

Figure 6: CSP-CaL- $\mathrm{CO}_{2}$ closed Brayton integration scheme 
A sensitivity analysis has been carried out in order to assess the global cycle performance under several Brayton cycle conditions. The cycle behaviour is analysed as affected by the pressure ratio (PR) value. PR is defined as the ratio between pressure at turbine inlet to pressure at outlet, which in this integration is given by the ratio of the carbonator pressure to the turbine outlet pressure. Figure 7 shows the relationship between $\mathrm{PR}$ and the carbonator inlet stream $(\mathrm{CaO}$ and $\mathrm{CO}_{2}$ ) temperatures by keeping a fixed value of the carbonator pressure at 7 bar. As PR is increased, the turbine outlet temperature is decreased (lower value of enthalpy), which implies a lower heating capacity on the carbonator inlet streams (by means of the heat exchangers HXG, $\mathrm{HXI}$ and HXE in Figure 6) and therefore more carbonation heat must be used to bring the $\mathrm{CaO}$ and $\mathrm{CO}_{2}$ streams to the carbonation temperature. Thus, on one hand, a high value of PR yields a higher power production in the Brayton turbine, which increases the global cycle performance. On the other, it reduces the heat available for power production, which implies a lower $\mathrm{CO}_{2}$ mass flow rate entering into the carbonator as heat transfer fluid (left side of Figure 6). The effect of increasing PR and temperature on the global plant efficiency is shown in Figure 8. As can be seen, an increase of the carbonator temperature leads always to a higher global efficiency whereas efficiency at a given temperature has a maximum at a given value of PR.

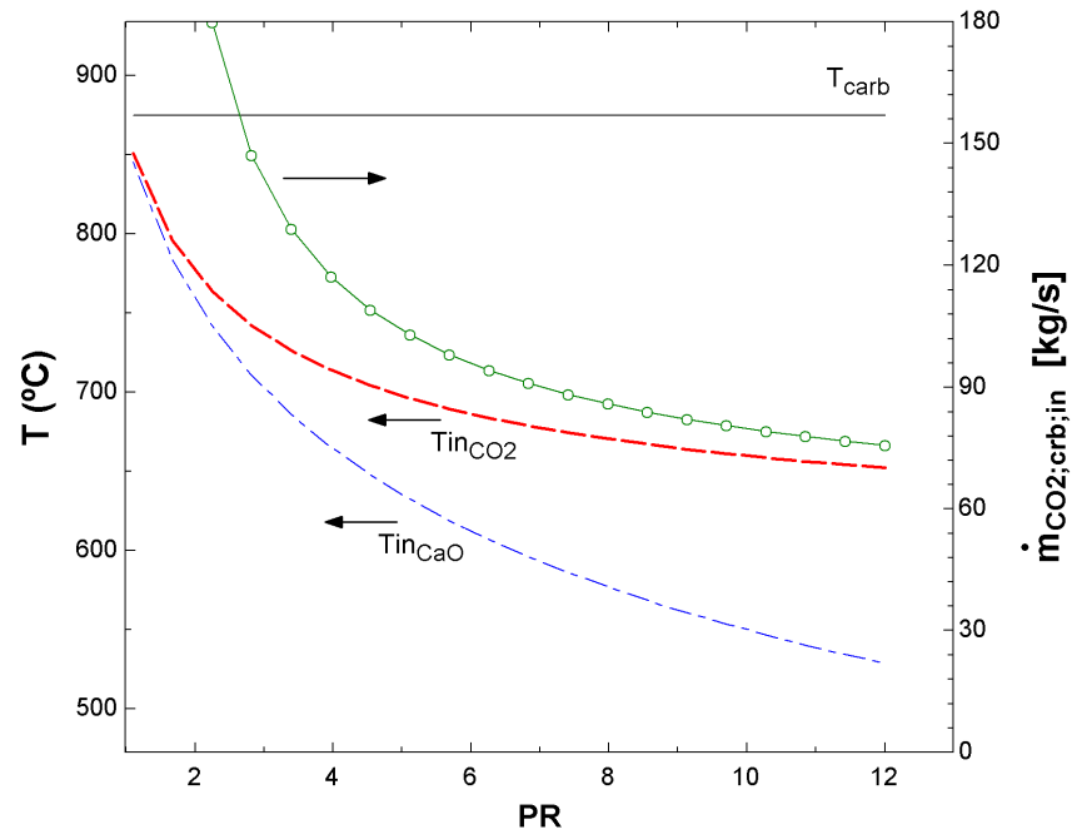

Figure 7: Left axis: Temperature of $\mathrm{CaO}\left(\mathrm{Tin}_{\mathrm{CaO}}\right)$ and $\mathrm{CO}_{2}\left(\mathrm{Tin}_{\mathrm{CO} 2}\right)$ streams entering into the carbonator reactor as a function of Pressure Ratio (PR). Right axis: $\mathrm{CO}_{2}$ mass flow rate entering into the carbonator. The carbonator temperature $\left(\mathrm{T}_{\text {carb }}\right)$ is fixed to $875^{\circ} \mathrm{C}$ 


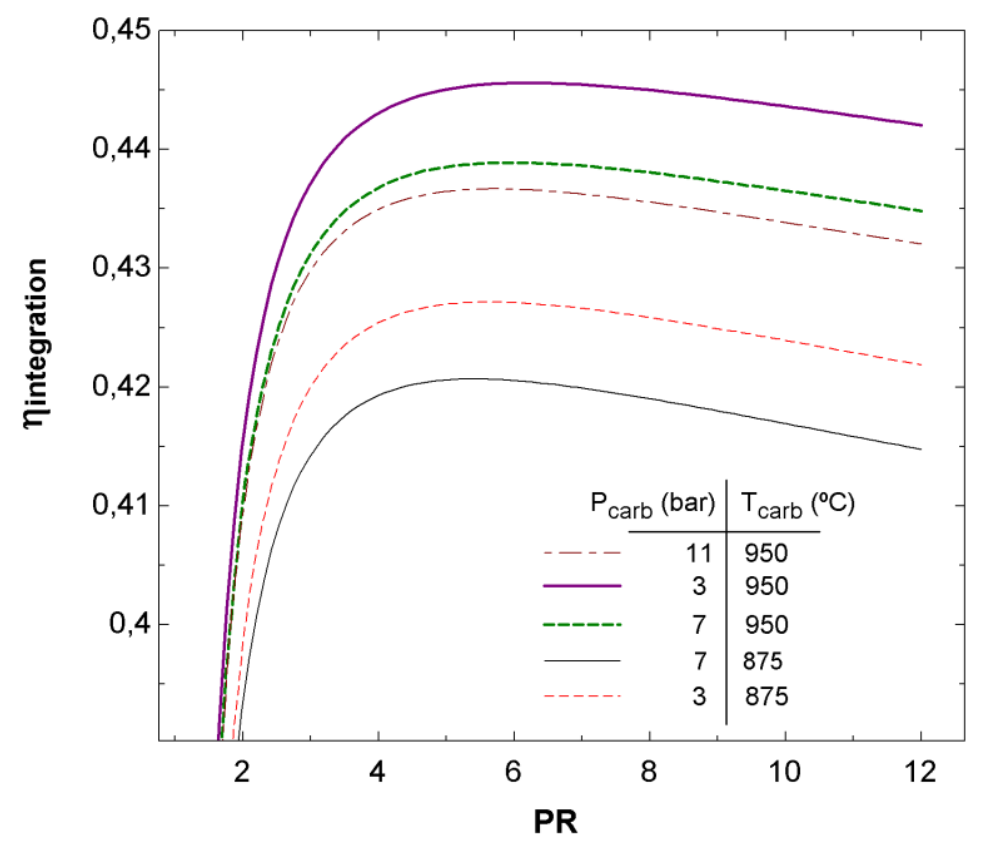

Figure 8: Global integration efficiency $\left(\mathrm{CO}_{2}\right.$ closed Brayton cycle) as a function of pressure ratio for several carbonator operation points as indicated.

\subsection{Indirect integration}

Regarding to indirect power cycle integration, the heat from the carbonator is transferred to the power cycle through a heat exchanger network. In this section a Rankine Reheat cycle and a supercritical $\mathrm{CO}_{2}$ recompression cycle are analysed. Moreover, a special case based on a combined cycle is investigated.

\section{a Reheat Rankine cycle}

Currently commercial CSP tower plants incorporate the steam Rankine power cycle technology for power production [28]. As a previous step to integration within the CSP-CaL cycle, a simple reheat Rankine cycle has been modelled to analyse the power cycle efficiency. Figure 9 shows a schematic of the cycle model, which is based on a reheat Rankine cycle with regeneration from five feed-water heaters (HE1:4), one of which is a total mixer exchanger type (DEA). For this reason, a series of steam extractions (Figure 9) are realized. The steam operational parameters and benchmarking have been chosen from data of similar real power plants [46,47]. Turbine and pump efficiencies values of 0.9 have been considered, as well as heat exchangers minimum temperature difference of $10^{\circ} \mathrm{C}$. On the other hand, a $1 \%$ pressure drop is assumed in all heat exchangers. Tables 2 and 3 show the main simulation results obtained for the system schematized in Figure 9. 


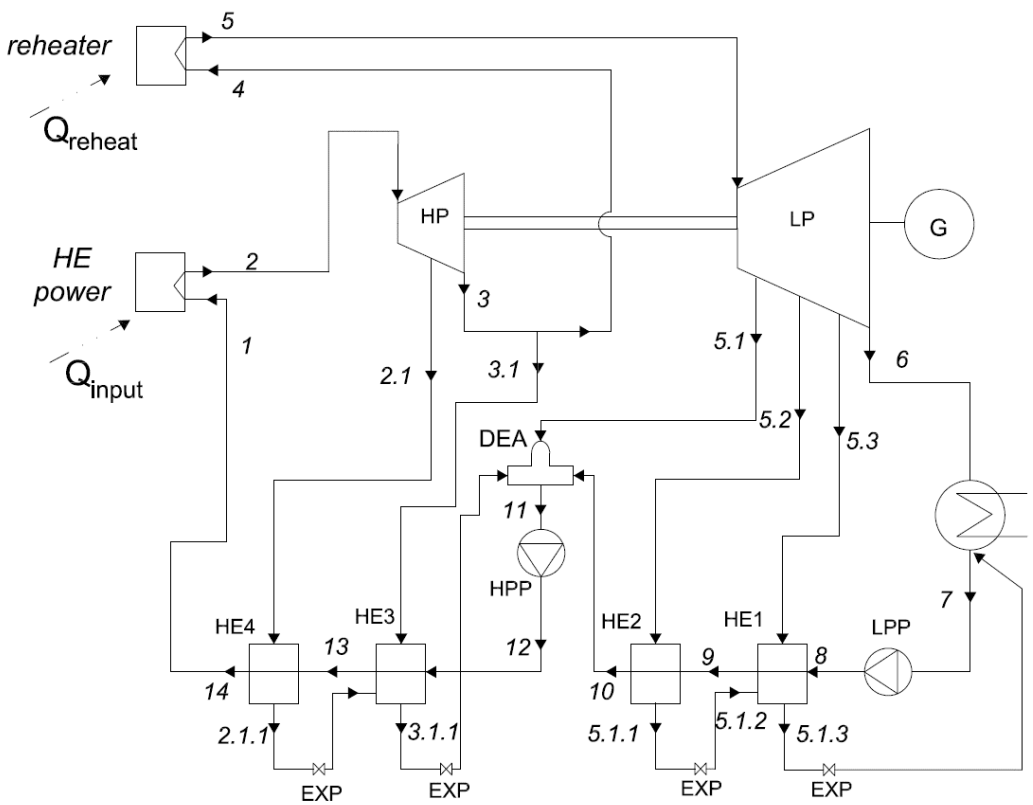

Figure 9: Base reheat Rankine cycle layout

Table 2: Main simulation Rankine cycle results for a 50MWth steam power cycle $\left(P_{v v}=160 \mathrm{bar}, T_{v v}=\right.$ $\left.540 / 540^{\circ} \mathrm{C}\right)$

\begin{tabular}{|c|c|}
\hline$Q_{\text {input }}$ & $50 \mathrm{MW}_{\text {th }}$ \\
\hline$Q_{\text {reheat }}$ & $9.1 \mathrm{MW}_{\text {th }}$ \\
\hline$W_{\text {pump }, H P P}$ & $0.35 \mathrm{MW}_{\mathrm{e}}$ \\
\hline$W_{\text {pump }, L P P}$ & $0.03 \mathrm{MW}_{\mathrm{e}}$ \\
\hline$W_{\text {turb }, H P}$ & $6.99 \mathrm{MW}_{\mathrm{e}}$ \\
\hline$W_{\text {turb }, L P}$ & $18.82 \mathrm{MW}_{\mathrm{e}}$ \\
\hline$P_{\text {HE1 }}$ & $5.46 \mathrm{MW}_{\text {th }}$ \\
\hline$P_{\text {HE2 }}$ & $2.68 \mathrm{MW}_{\text {th }}$ \\
\hline$P_{\text {HE3 }}$ & $8.64 \mathrm{MW}_{\text {th }}$ \\
\hline$P_{\text {HE4 }}$ & $3.88 \mathrm{MW}_{\text {th }}$ \\
\hline$\eta_{\text {cycle }}$ & $43.07 \%$ \\
\hline
\end{tabular}

Table 3: Stream data for a 50MWth steam power cycle $\left(P_{v v}=160 \mathrm{bar}, T_{v v}=540 / 540^{\circ} \mathrm{C}\right)$

\begin{tabular}{|c|c|c|c|c|c|c|c|}
\hline Stream & $\dot{m}(\mathrm{~kg} / \mathrm{s})$ & $T\left(\mathrm{o}^{\mathrm{o}} \mathrm{C}\right)$ & $P($ bar $)$ & Stream & $\dot{m}(\mathrm{~kg} / \mathrm{s})$ & $T\left({ }^{\mathrm{o}} \mathrm{C}\right)$ & $P($ bar $)$ \\
\hline 1 & 22.67 & 315.9 & 204 & 5.2 .1 & 1.16 & 132 & 4.95 \\
\hline 2 & 22.67 & 540 & 200 & 5.3 & 1.08 & 99.63 & 1 \\
\hline 2.1 & 2.45 & 452.1 & 93 & 5.3 .1 & 2.23 & 58.6 & 0.99 \\
\hline 2.1 .1 & 2.45 & 294.8 & 92.1 & 6 & 14.29 & 43.77 & 0.09 \\
\hline 3 & 20.18 & 352 & 46 & 7 & 16.53 & 43.58 & 0.09 \\
\hline 3.1 & 2.02 & 352 & 46 & 8 & 16.53 & 43.59 & 18.4 \\
\hline 3.1 .1 & 4.51 & 215 & 45.5 & 9 & 16.53 & 122 & 18.2 \\
\hline 4 & 18.16 & 352 & 46 & 10 & 16.53 & 159.8 & 18 \\
\hline 5 & 18.16 & 540 & 45.5 & 11 & 22.67 & 202.9 & 18 \\
\hline 5.1 & 1.63 & 403.7 & 18 & 12 & 22.67 & 205 & 208 \\
\hline 5.2 & 1.16 & 248.5 & 5 & 13 & 22.67 & 284.8 & 205.9 \\
\hline
\end{tabular}


Once the power cycle block model is developed, this is integrated into the CSP-CaL scheme. 400 CSP-CaL main operation parameters are the same as in previous schemes (Figure 6). Pure $\mathrm{CO}_{2}$ 401 is used for carbonation, which allows operating at high carbonator temperatures.

Figure 10 shows a schematic representation of the CSP-CaL-Rankine integration and main simulation results considering carbonation at $875^{\circ} \mathrm{C}$ under atmospheric pressure. The integration efficiency is shown in Figure 11 as a function of the carbonator pressure for diverse temperatures. As can be seen, the maximum efficiency (around $35.5 \%$ ) is obtained at $875^{\circ} \mathrm{C}$ operating under atmospheric pressure, which is well over current CSP plant performances. Higher temperatures in the carbonator would require higher minimum carbonator pressures for carbonation to be thermodynamically favourable at which efficiency is decreased.

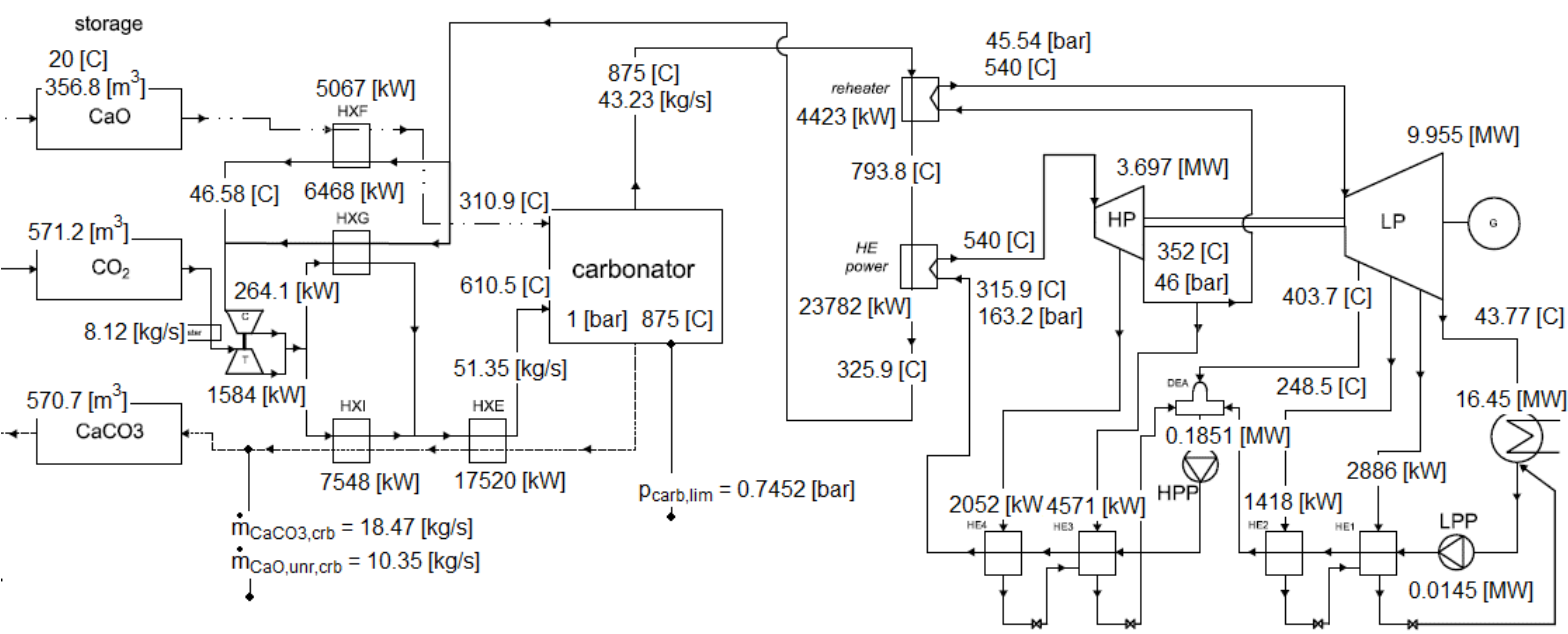




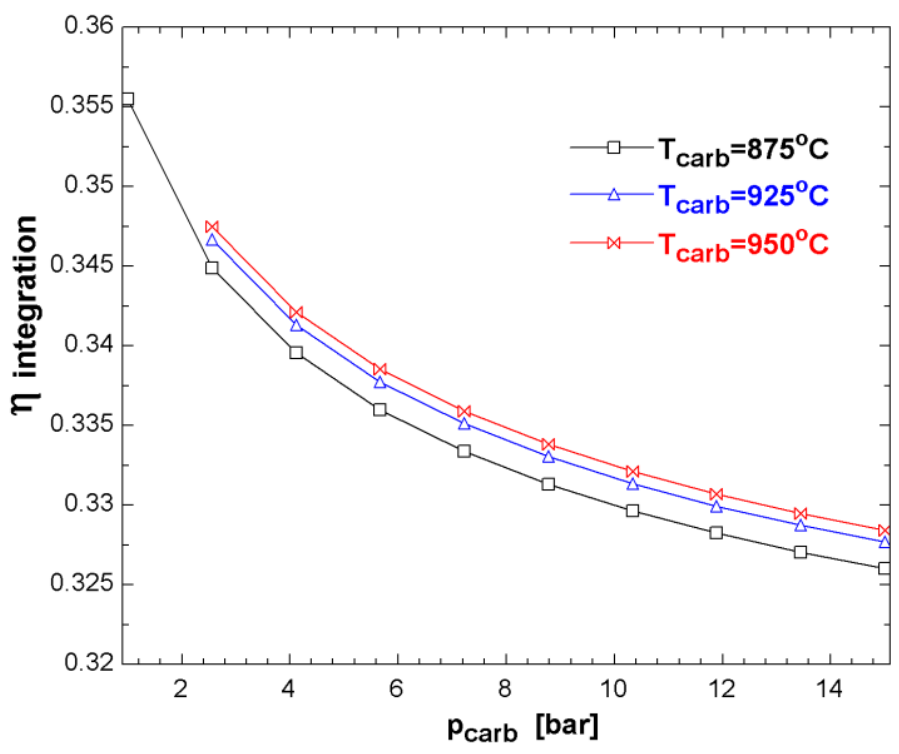

Figure 11: Efficiency of the CaL-Rankine integration as a function of carbonator pressure and for diverse temperatures. Note that a minimum carbonator pressure is required according to thermochemical equilibrium as temperature is increased.

A sensitivity analysis has been carried out in which the main Rankine cycle parameters have been tuned. As can be seen in Figure 12, the global integration efficiency is promoted by increasing live steam conditions (pressure $\left(\mathrm{P}_{\mathrm{vv}}\right)$ and temperature $\left(\mathrm{T}_{\mathrm{vv}}\right)$ ). It may be also seen that efficiency is enhanced as the reheat temperature is increase.
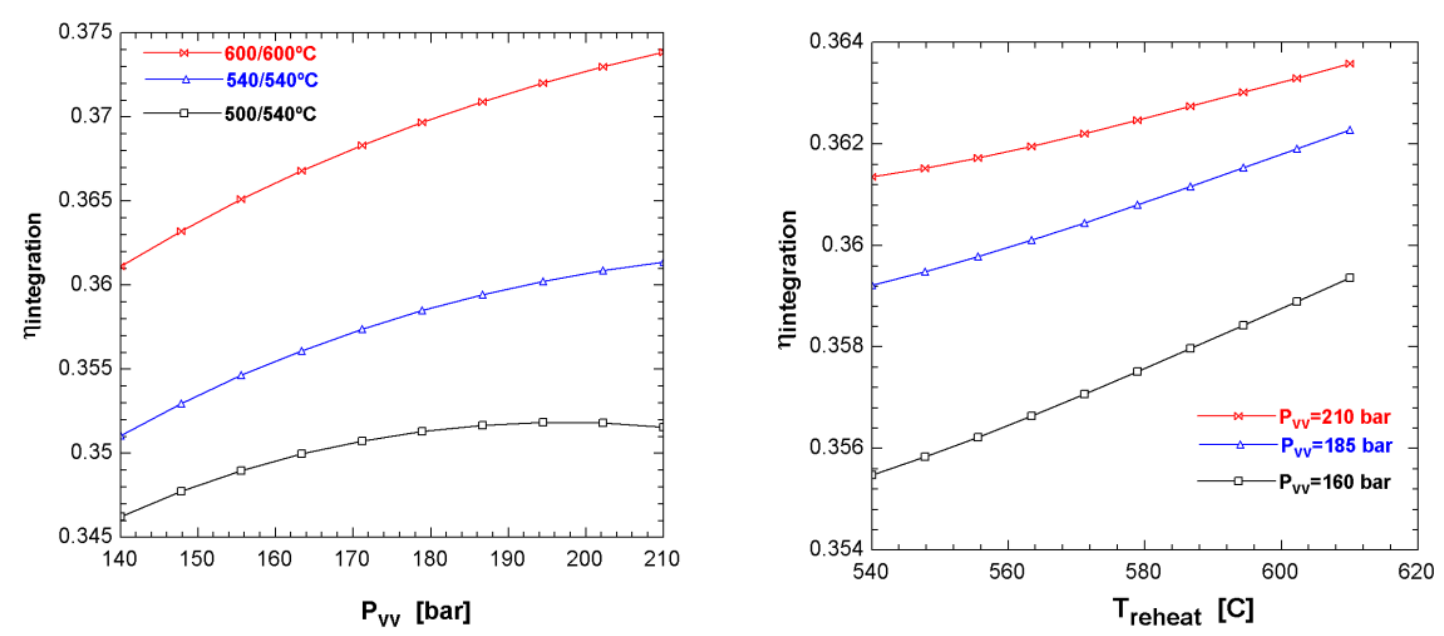

Figure 12: Global integration efficiency as a function of (LEFT) steam turbine inlet and (RIGHT) reheat temperature conditions

As seen in Figure 10, the preheat water of the Rankine cycle is heated by the exhaust $\mathrm{CO}_{2}$ stream from the carbonator in a heat recovery steam generator (HRSG) until super-heated status is reached. One key parameters in Rankine power cycles is the HRSG efficiency, which can be analysed from the pinch point value across the steam production process. Figure 13 shows that lower values of the pinch point (higher HRSG efficiency) causes an increase in the global cycle efficiency. 

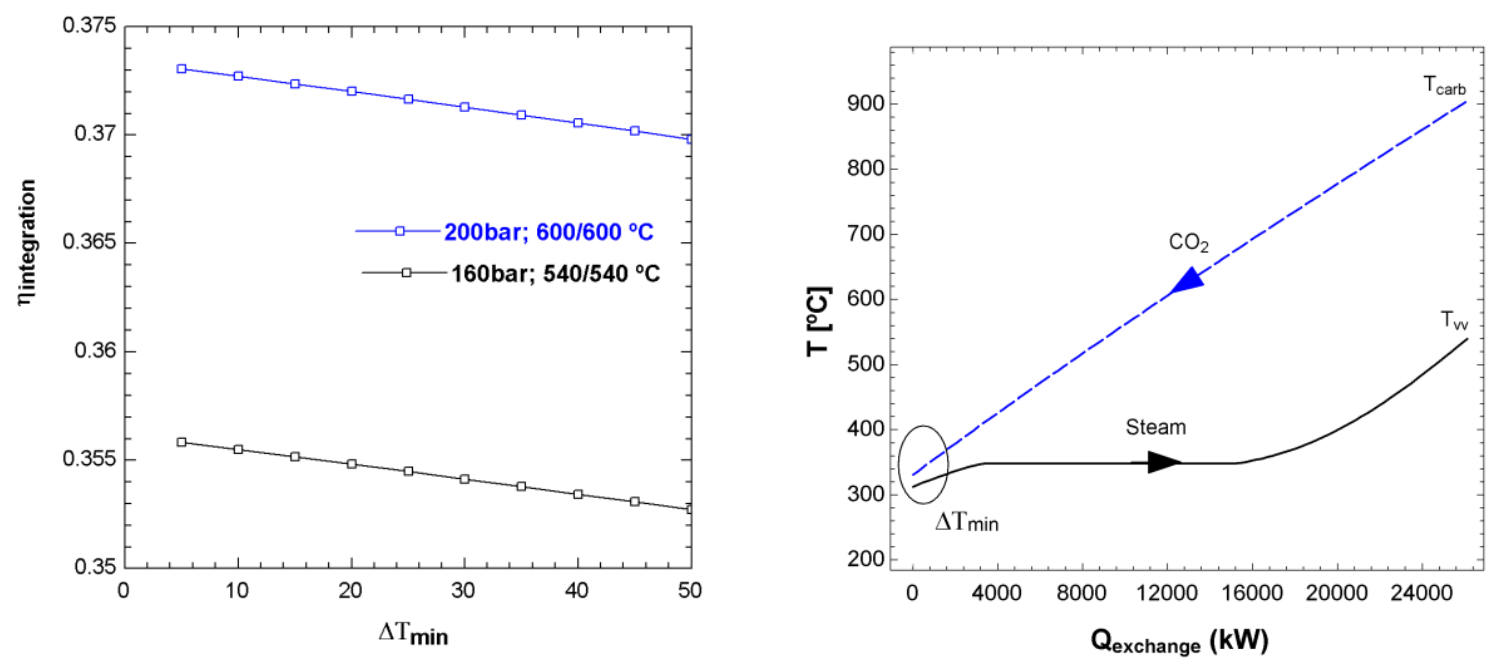

Figure 13: Global integration efficiency as a function of minimum temperature approach in HRSG

The supercritical $\mathrm{CO}_{2}\left(\mathrm{sCO}_{2}\right)$ Brayton cycle, which was originally introduced by Feher [48], has emerged in the last years as a promising technique for high-efficiency power production. It basically consists of a closed-loop Brayton cycle that operates entirely above $\mathrm{CO}_{2}$ critical pressure $\left(73.77\right.$ bar and $\left.30.98^{\circ} \mathrm{C}\right)$ and presents a high drop in compressibility, which brings about a similar reduction in compression work while the turbine operates with $\mathrm{CO}_{2}$ in a close to ideal behaviour. Among different layouts proposed for $\mathrm{sCO}_{2}$ cycles, a recompression scheme seems to be the highest efficiency cycle [49], which is thus the one used in the present study. Figure 14 shows the recompression cycle model. An important feature of the regeneration process in the $\mathrm{sCO}_{2}$ Brayton cycle is that the specific heat of the cold side is 2-3 times higher than the hot side. Thus, the $\mathrm{CO}_{2}$ stream is split (stream $5 \mathrm{~b}$ in Figure 14a) to compensate for the specific heat difference in the low temperature recuperator, which maximizes the heat recuperation.

$\mathrm{CSP}-\mathrm{sCO}_{2}$ integration models have been already developed to increase the CSP power plant performance. Thus, Chacartegui et al. [50] compared the integration of supercritical and transcritical carbon dioxide cycles as well as a combined cycle composed by a topping Brayton $\mathrm{CO} 2$ cycle and a bottoming Organic Rankine Cycle. Iverson et al. [51] presents the behaviour of Brayton cycle turbomachinery including a data set for stable supercritical $\mathrm{CO} 2$ Brayton cycle operation. Moreover, Ma et al. [52] analyses the integration of sCO2 power cycles by considering sensible heat storage (thermocline system). One of the most important advantages of the $\mathrm{sCO}_{2}$ Brayton cycle is its compact turbomachinery, albeit it is still under development [53]. $\mathrm{A} \mathrm{SCO}_{2}$ technology review is presented in [45], from which values on turbomachinery efficiency and pressure drops are taken in the present work. Thus, the recompression $\mathrm{sCO}_{2}$ cycle has been simulated using data specified in table 3 .

Table 4: Input data parameters for the $\mathrm{sCO}_{2}$ cycle [45]

\begin{tabular}{|c|c|}
\hline$\eta_{c}(\%)$ & 85 \\
\hline$\eta_{t}(\%)$ & 90 \\
\hline$\varepsilon_{\text {rec }}(\%)$ & 95 \\
\hline$\Delta P_{R, h o t}(\%)$ & 0.5 \\
\hline
\end{tabular}


464

465

466

467

468

469

470

471

472

473

474

475

476

477

478

479

480

481

\begin{tabular}{|c|c|}
\hline$\Delta P_{R, \text { cold }}(\%)$ & 1.5 \\
\hline$\Delta P_{R, H E}(\%)$ & 0.5 \\
\hline
\end{tabular}

Figure $14 \mathrm{a}$ shows the recompression $\mathrm{sCO}_{2}$ Brayton scheme proposed. Thermodynamic parameters of the streams involved in the cycle are shown in Figure $14 \mathrm{~b}$ in a temperature (T)entropy (S) diagram. Main sCO2 cycle simulation results are shown in Tables 5 and 6 . A cycle efficiency of around $41 \%$ is obtained from this configuration, which is in agreement with results from previous works [45,54].

(a)
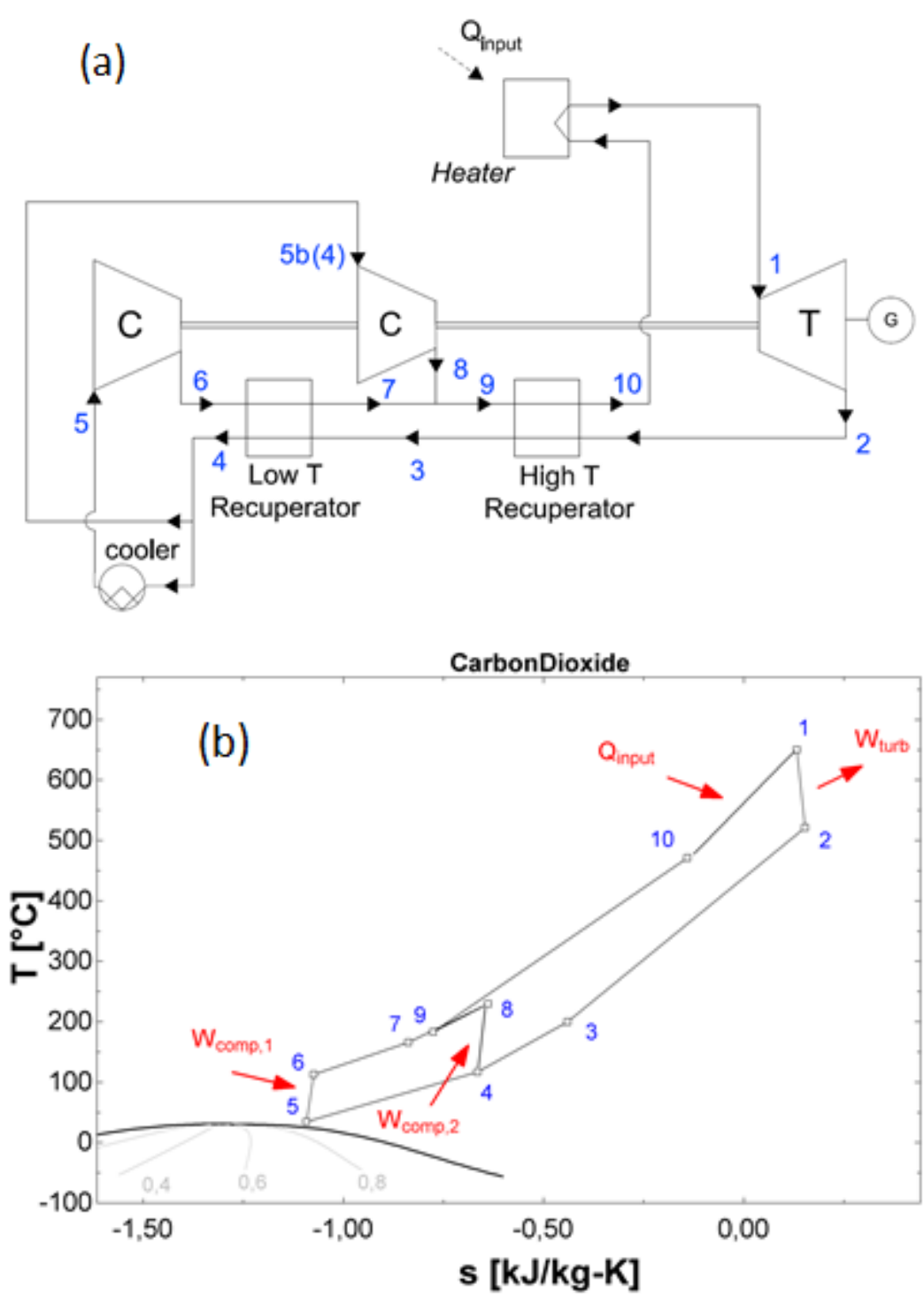

Figure 14: (a) Base recompression- $\mathrm{sCO}_{2}$ Brayton cycle layout. (b) Temperature-entropy diagram

Once the recompression $\mathrm{sCO}_{2}$ cycle is analysed and benchmarked it is integrated in the CSP$\mathrm{CaL}$ configuration as shown in Figure 15. A global integration efficiency close to $32 \%$ is achieved, although it must be taken into account that a large amount of energy linked to the cooling process before the compression stage is not used. This suggests that a bottoming cycle could serve to improve the cycle performance [50]. 
Table 5: Main $\mathrm{sCO}_{2}$ cycle simulation results

\begin{tabular}{|c|c|}
\hline$Q_{\text {input }}$ & $50 \mathrm{MW}_{\text {th }}$ \\
\hline$W_{\text {comp }, 1}$ & $7.14 \mathrm{MW}_{\mathrm{e}}$ \\
\hline$W_{\text {comp }, 2}$ & $5.74 \mathrm{MW}_{\mathrm{e}}$ \\
\hline$W_{\text {turb }}$ & $33.38 \mathrm{MW}_{\mathrm{e}}$ \\
\hline$\eta_{\text {cycle }}$ & $41.01 \%$ \\
\hline$\phi_{\text {cycle }}$ & $69 \%$ \\
\hline
\end{tabular}

483

484

Table 6: Stream data for $\mathrm{sCO}_{2}$ recompression cycle

\begin{tabular}{|c|c|c|c|}
\hline Stream & $\dot{m}(\mathrm{~kg} / \mathrm{s})$ & $T\left({ }^{\circ} \mathrm{C}\right)$ & $P($ bar $)$ \\
\hline 1 & 223.6 & 650 & 213.9 \\
\hline 2 & 223.6 & 521.1 & 78 \\
\hline 3 & 223.6 & 200.2 & 77.61 \\
\hline 4 & 223.6 & 117.2 & 77.22 \\
\hline 5 & 158.8 & 35 & 75 \\
\hline $5 \mathrm{~b}$ & 64.85 & 117.2 & 77.22 \\
\hline 6 & 158.8 & 113.1 & 225 \\
\hline 7 & 158.8 & 166.0 & 223.9 \\
\hline 8 & 64.85 & 229.8 & 221.6 \\
\hline 9 & 223.6 & 183.1 & 221.6 \\
\hline 10 & 223.6 & 471 & 218.3 \\
\hline
\end{tabular}

\begin{tabular}{|l|}
\hline Global integration efficiency $\mathbf{0 , 3 1 9 4}$ \\
\hline \hline Electricity $_{\text {qenerated }}=452,8[\mathrm{MWh}]$ \\
Electricity $_{\text {used }}=230,9[\mathrm{MWh}]$ \\
Electricity $_{\text {produced }}=221,9[\mathrm{MWh}]$ \\
\hline \hline$\eta_{\mathrm{sCO}, \text { cvcle }}=0,4809$ \\
$\phi_{\mathrm{sCO}, \text { cycle }}=0,69$ \\
\hline
\end{tabular}

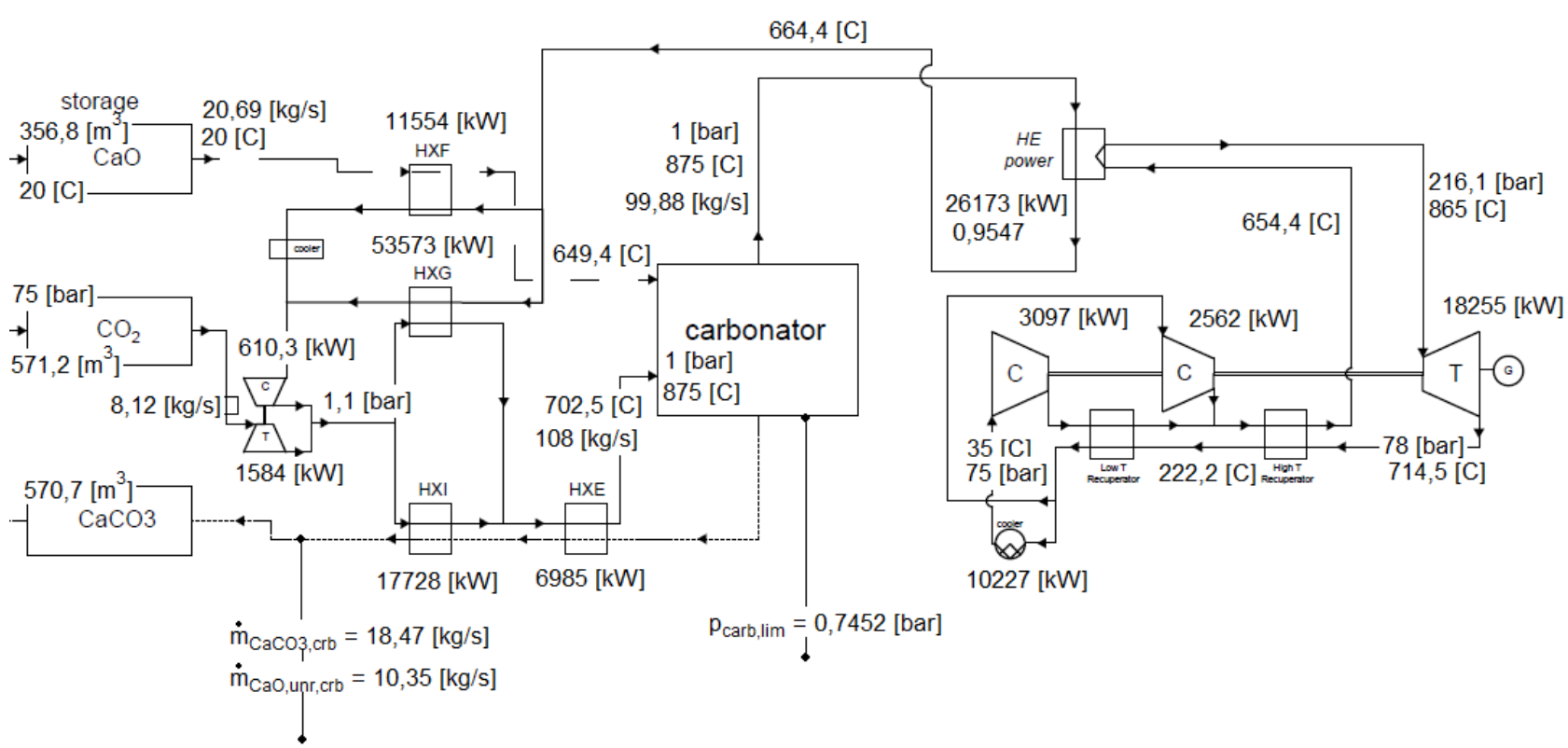

Figure 15: CSP-CaL- $\mathrm{sCO}_{2}$ integration scheme and main simulation results 
Results from a sensitivity analysis are shown in Figure 16. It is observed that the recuperation process in the $\mathrm{sCO}_{2}$ Brayton cycle greatly influences the thermal efficiency since $\mathrm{CO}_{2}$ properties are very sensitive to pressure and temperature near the critical point. Therefore, the hot and cold sides in the regenerator are strongly unbalanced. As can be seen in Figure 16, by increasing the turbomachinery efficiency (which depends upon further technology development) the global cycle performance is significantly enhanced.

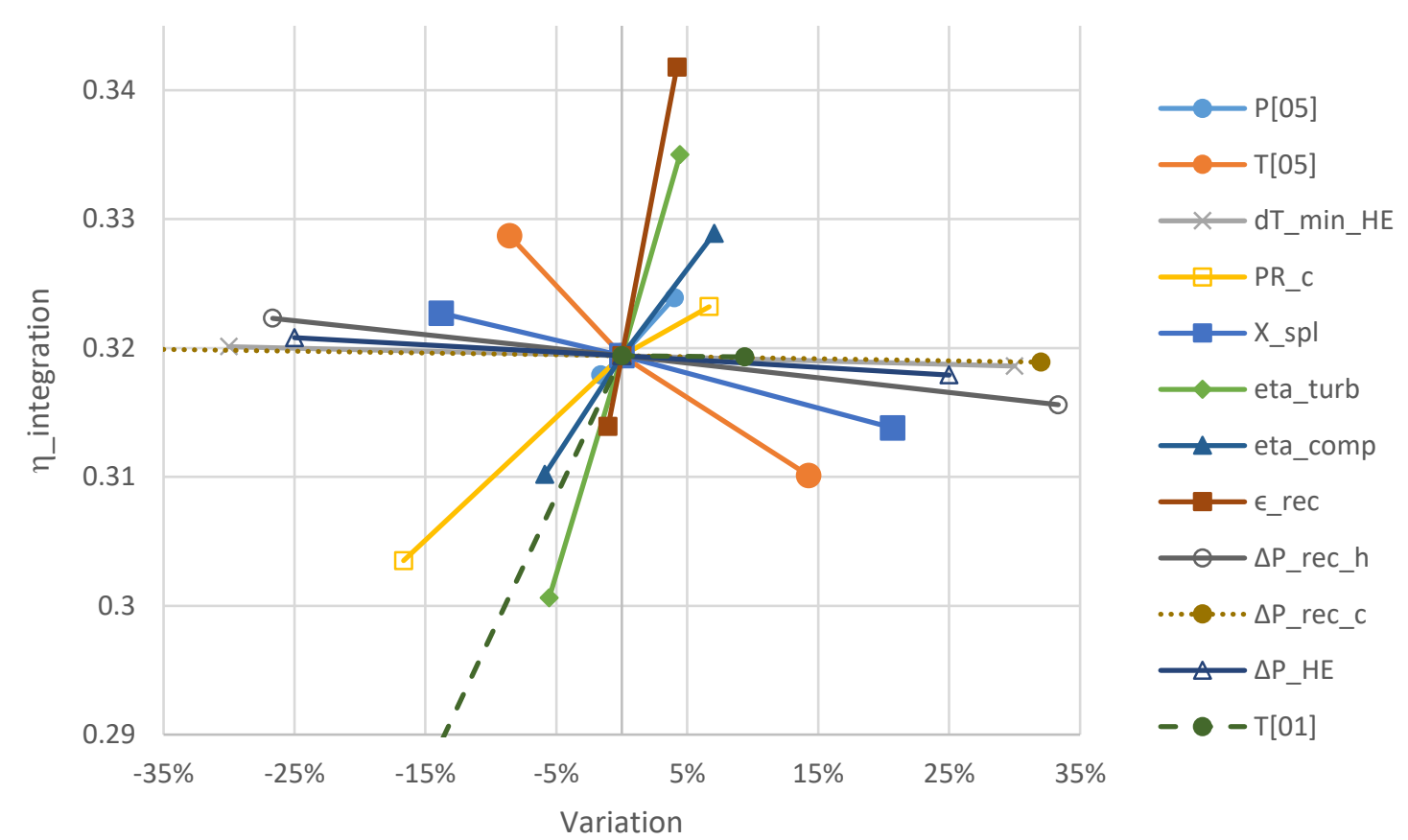

Figure 16: Sensitivity analysis results of the CSP-CaL- $\mathrm{sCO}_{2}$ integration.

\section{c Combined cycle}

The combined cycle is based on the integration of two subsystems consisting of a gas turbine (Brayton cycle) and a steam turbine (Rankine cycle), which leads to an improvement of efficiency due to the synergy of both cycles [55].

A number of integrated solar combined cycle (ISCC) systems have been proposed to improve the power plant efficiency [56,57]. ISCCS power plants currently in operation employ the parabolic trough concentrator technology. Further work is still needed to advance in the technological readiness of solar tower - ISCC power plants [58]. ISCC cycles operate using a solar-fuel combination $[59,60]$, with the gas turbine being fuelled by a non-solar source (based on fossil or renewable fuel) due to the temperature limitation in CSP power plants imposed by degradation of molten salts and thermal radiation losses at the focal point. Solar power share in ISCC power plants is on average below 34\% [58]. Compared with the solar-only power plants, ISCC plants exhibit several advantages such as higher solar-to-electricity conversion performance. Moreover, thermal inefficiency associated with the daily start-up and shutdown of the steam turbine can be avoided [61]. Another configuration proposed in a recent work [62] evaluates a combined cycle based on a closed Brayton and organic Rankine cycle for solar power tower plants by means of energy and exergy analysis, showing that higher performance than using steam and supercritical $\mathrm{CO}_{2}$ cycles can be achieved. 
Figure 17 shows the global cycle integration proposed by considering a combined cycle for power production. The combined cycle involves a hybrid direct-indirect power cycle integration with the CSP-CaL system. The $\mathrm{CO}_{2}$ stream exiting the carbonator is expanded in a gas turbine as a previous step for transferring heat to steam cycle through a HRSG. Main simulation results are shown also in Figure 17.

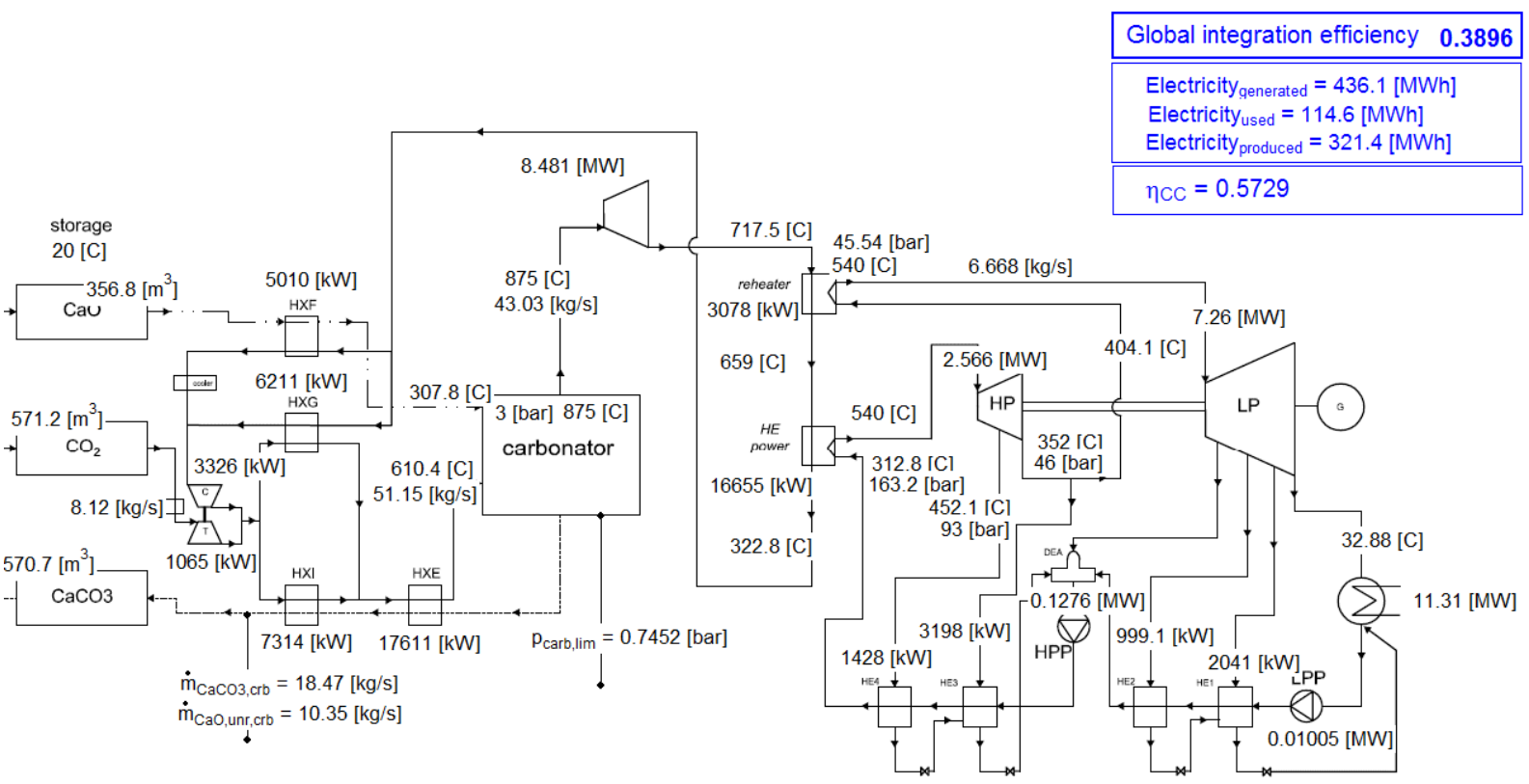

Figure 17: CSP-CaL- CC integration scheme and main simulation results

Figure 18 shows the global cycle performance as a function of the carbonator pressure (or, equivalently, the inlet turbine pressure) for different values of the turbine outlet pressure. As can be seen, a higher performance is obtained by decreasing the outlet turbine pressure, reaching a maximum value of $40.4 \%$ for operation under an inlet/outlet turbine pressure ratio of 3.6/1. In order to simplify the heat exchanger network, an atmospheric outlet turbine pressure will be next considered.

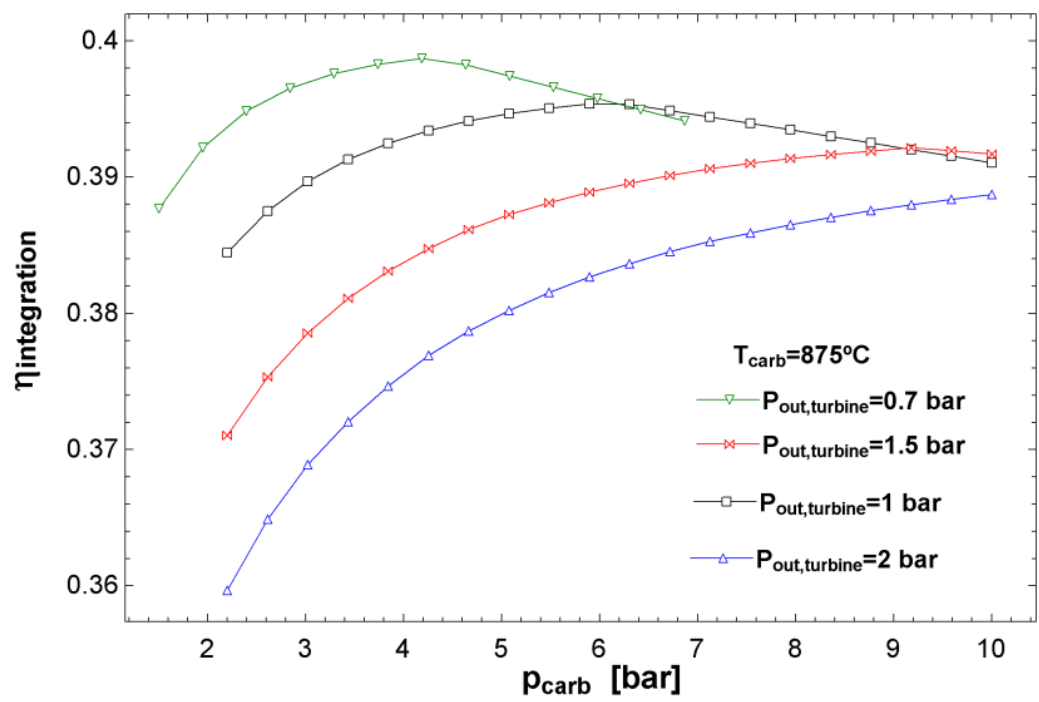

Figure 18: Efficiency of the CSP-CaL-CC integration as a function of the carbonator pressure for several values of the Brayton turbine outlet pressure. 


\section{Comparative analysis on the CaL-CSP-power cycle integrations}

In order to compare the performances of the diverse CSP-CaL-power cycle integrations a sensitivity analysis has been carried out using reference parameters for which the efficiency of these integrations is optimized. Main power cycle parameters for each integration scheme are given in Table 7. A carbonator temperature of $875^{\circ} \mathrm{C}$ has been selected, which guarantees carbonation under the different carbonator pressures of each cycle. Unless otherwise indicated, the values of the parameters employed for the CaL cycle are those previously specified in Table 1. Note that temperatures for steam turbine in the case of the combined cycle are conditioned by the Brayton turbine exit and therefore the values shown in this table correspond to the maximum temperatures achievable.

Table 7: Main power cycle parameters for each integration scheme

\begin{tabular}{|c|c|c|c|c|}
\hline & $\begin{array}{c}\text { Closed } \mathrm{CO}_{2} \\
\text { Brayton }\end{array}$ & $\begin{array}{c}\text { Reheat } \\
\text { Rankine }\end{array}$ & $\begin{array}{c}\mathrm{sCO}_{2} \\
\text { Recompression }\end{array}$ & $\begin{array}{c}\text { Combined } \\
\text { cycle }\end{array}$ \\
\hline$P_{\text {out }, \text { turb }}($ bar $)$ & 1 & - & - & 1 \\
\hline$P_{\text {carb }}($ bar $)$ & 3.2 & 1 & 1 & 3.2 \\
\hline$P_{v v}($ bar $)$ & - & 160 & - & 160 \\
\hline$T_{\text {carb }}\left({ }^{\circ} C\right)$ & 875 & 875 & 875 & 875 \\
\hline$T_{v v}\left({ }^{\circ} C\right)$ & - & 540 & - & 540 \\
\hline$T_{\text {reheat }}\left({ }^{\circ} C\right)$ & - & 540 & - & 540 \\
\hline$\Delta T_{\text {min }}$ & - & 10 & 10 & 10 \\
\hline$P[05]($ bar $)$ & - & - & 75 & - \\
\hline$T[05]\left({ }^{\circ} C\right)$ & - & - & 32 & - \\
\hline$P R$ & 3.2 & - & 3 & 3.2 \\
\hline$X$ & 0.5 & 0.5 & 0.5 & 0.5 \\
\hline
\end{tabular}

Figure 19 shows the global integration efficiency obtained for the different power cycles analysed in this work as a function of the carbonator pressure. As can be seen, the $\mathrm{CO}_{2}$ closed cycle direct integration yields the best efficiency results. Only by means of the indirect integration is possible to operate the carbonator under atmospheric pressure, being the efficiency hampered in this integration as the carbonator pressure is increased further. The opposite trend occurs in the $\mathrm{CO}_{2}$ closed and $\mathrm{CC}$ power cycles. Using these power cycles, the global efficiency is promoted as the carbonator pressure is increased up to a certain optimum value, which is around 4.2 bar for the $\mathrm{CO}_{2}$ closed cycle and 5.1 bar for the CC cycle (atmospheric turbine outlet pressure). Results show also that despite $\mathrm{sCO}_{2}$ recompression cycle could be a potentially attractive choice from a thermodynamic point of view, the conservative values used for the turbomachinery efficiencies (in accordance with the current state of art $[45,47])$ prevents the $\mathrm{CSP}-\mathrm{CaL}-\mathrm{SCO}_{2}$ cycle integration from reaching very high global efficiencies. Efficiency results are plotted in Figure 20 as a function of the $\mathrm{CaO}$ average conversion. Generally, the enhancement of $\mathrm{CaO}$ conversion promotes efficiency as would be expected. 


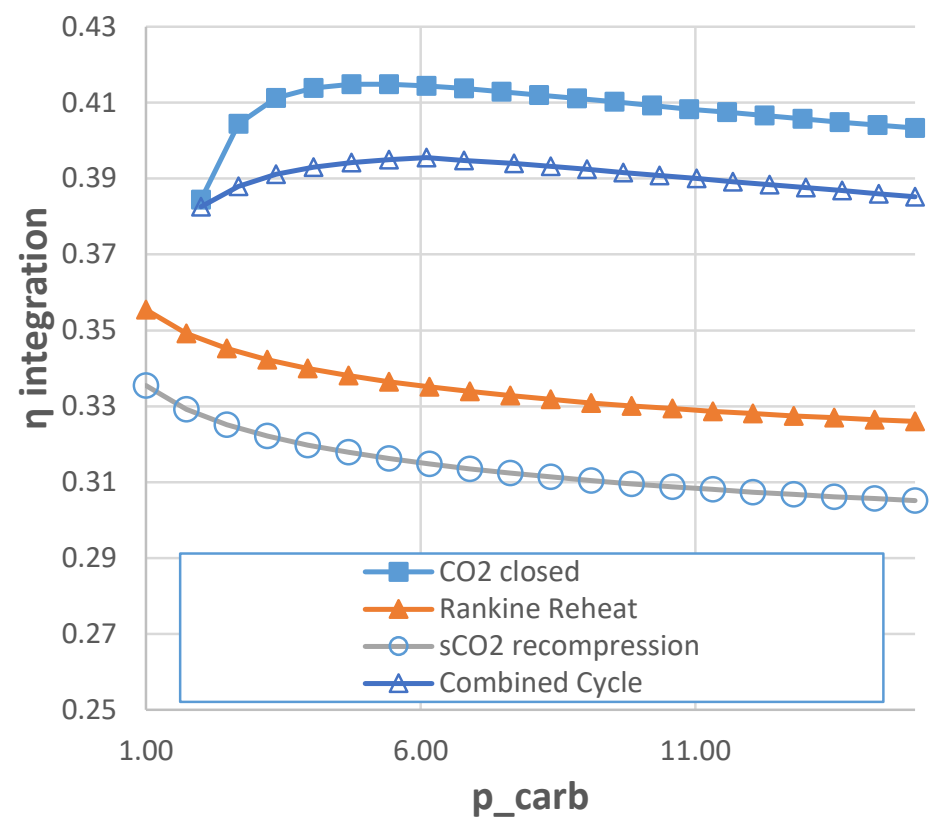

Figure 19: Global cycle integration efficiency as a function of carbonator pressure for the different power cycles coupled to the CSP-CaL system (using data showed in Table 7).

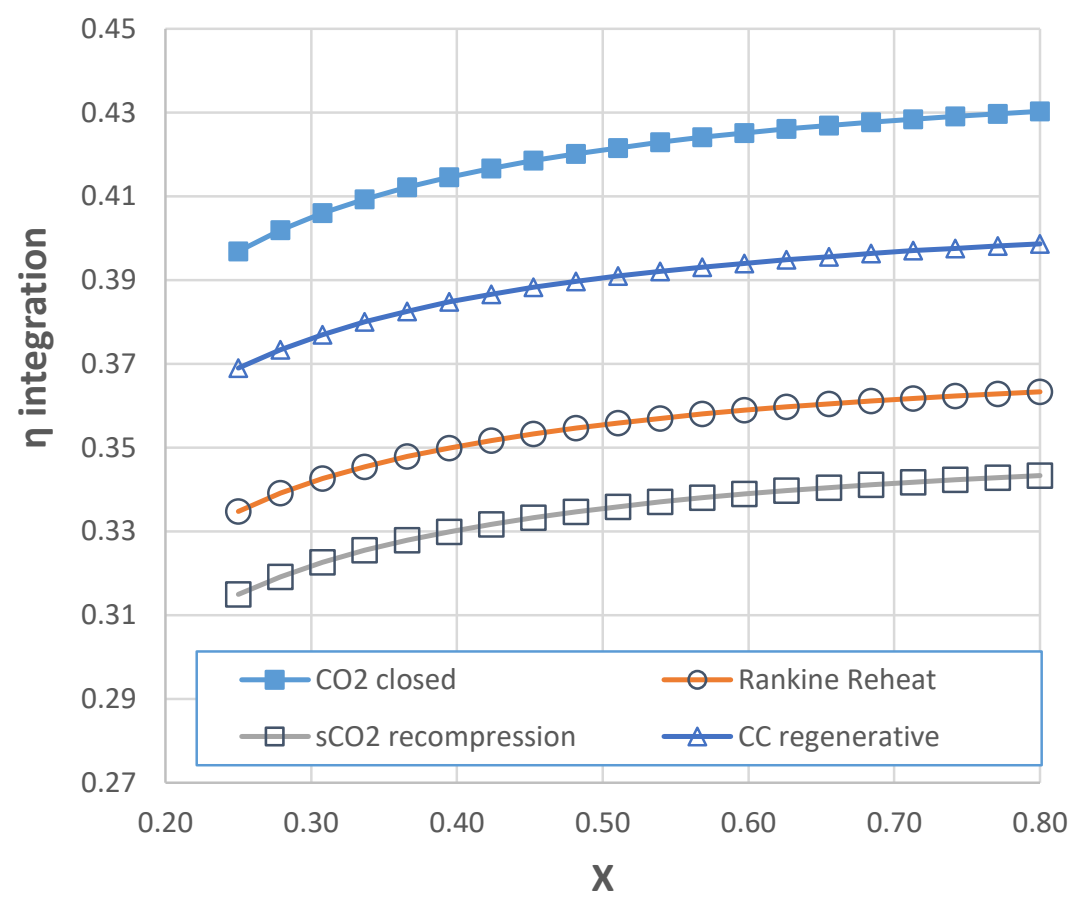

Figure 20: Global cycle integration efficiency as a function of average $\mathrm{CaO}$ conversion for the different power cycles coupled to the CSP-CaL system (using data showed in Table 7).

Additional considerations regarding costs must be addressed to further assess the applicability of these power cycle integrations in the CSP-CaL. As this technology is in an early concept stage, data from prototypes or experimental installations are not available for the TCES core. 
A detailed economic prospective analysis is under development and will be presented in next works. However, some preliminary considerations can be already made by extrapolating components information from other technologies. In commercial CSP plants, the power block cost percentage is estimated around 32\% [63] and power cycle integration has a critical influence on capital investment. Some considerations may be made also on the maturity of the power technologies analysed in this work. These include one full mature technology (steam power cycle), two fully feasible power technologies with already available commercial components (real gas $\mathrm{CO}_{2}$ closed cycle and the derived combined cycle) and a promising power technology with great advances expected (supercritical $\mathrm{CO}_{2}$ cycle).

Steam power cycles fulfilling specific conditions for their integration in CSP plants (optimized for complex and challenging cycle conditions) are at the commercial level [64]. For conventional steam power cycles, capital and O\&M costs can be estimated as $1280 \$ / \mathrm{kW}$ and 5.7 $\$ / \mathrm{MWh}$, respectively [65]. For the $\mathrm{CO}_{2}$ closed-cycle gas turbine, although not fully available, main components are already usable or can be integrated from different applications. Thermal turbomachinery, compressors and turbines are already in use at commercial scale using as working fluid air, e.g. the Gelsenkirchen plant [66] and Oberhausen I [67], or Helium, e.g. Oberhausen II [67]. In the case of $\mathrm{CO}_{2}$ as working fluid, compressors are being widely analysed and tested in recent years as fundamental equipment within the Carbon Capture and Storage (CCS) technology $[68,69]$. Thermal machinery characteristics for the pressure ratios and temperatures presented in this work will be quite similar to the ones operating with air and combustion gases, as shown by Najjar et al. [70] for compressor pressure ratios of 5, compressor temperature inlet of $310 \mathrm{~K}$ and turbine temperature inlet of $1100 \mathrm{~K}$. Therefore, already available technologies for turbines and compressors could be employed. In the case of closed-Brayton cycles, the introduction of additional heat exchangers increases capital investment [50]. Therefore, technologies for the conditions presented in this work are already available, and costs for the fully developed technology could be expected as similar to the ones in the range between current gas turbines and combined cycles. For a $100 \mathrm{MWe}$ power block estimated capital and total O\&M costs for an open gas turbine combined cycle (considering only the power block) are around $660 \$ / \mathrm{kW}$ and 2.2 $\$ / \mathrm{MWh}$, respectively [65,71] whereas for an airopen Brayton cycle they can be estimated as $1026 \$ / \mathrm{kW}$ and 3.42 $\$ / \mathrm{MWh}$ respectively [72]. Finally, in the case of supercritical $\mathrm{CO}_{2}$ technology, in spite of that $\mathrm{sCO}_{2}$ cycle is a non-mature technology, in a project under development granted by US DOE through the Sunshot initiative [73] a power plant investment cost of $1200 \$ / \mathrm{kW}$ at the commercial stage is assumed [74,75].

Regarding the CaL thermochemical energy storage system, it implies an intrinsic benefit regarding life cycle cost and system sustainability as it is based on the use of low price, nontoxic and widely available natural $\mathrm{CaO}$ precursors such as limestone and dolomite. According to [76], the use of the CaL process for TCES would make it possible to achieve a thermal storage cost lower than $15 \$ / \mathrm{kWh}_{\mathrm{t}}$. This preliminary approach shows the potential of these integrations. Detailed and fully developed life cycle and economic analysis are under development and will be the subject of future works.

\section{Conclusions}

This manuscript analyses several CSP tower plant integration schemes with thermochemical energy storage (TCES) using the Calcium-Looping $(\mathrm{CaL})$ cycle. The work is focused on assessing the power production cycle. The CSP-CaL integration yields high temperatures (above $850^{\circ} \mathrm{C}$ ) at the power cycle inlet, which allows using high efficiency power cycles employed in fuel based power plants (or combined CSP-fuel power plants). Thus, the CSP-CaL integration achieves high density/long term storage capacity and lends itself for the integration 
In regards to direct-indirect cycles integration, results show that higher performance is achieved for direct integration. On the other hand, higher efficiencies are attained as the average $\mathrm{CaO}$ conversion is increased. Among the power cycles analysed in the present work, the $\mathrm{CO}_{2}$ closed Brayton cycle shows the best overall performance, reaching efficiencies potentially above 44$45 \%$ (including penalty for solids conveying) if the carbonator is operated at temperatures around $950^{\circ} \mathrm{C}$ and under pressures about 3.5 bar for atmospheric pressure at Brayton turbine outlet. Importantly, carbonation conditions in this integration allows for high values of the residual conversion of $\mathrm{CaO}$ derived from natural minerals such as limestone and dolomite as recently demonstrated by thermogravimetric studies. The wide availability, abundance, lack of corrosiveness, non-toxicity and cheapness $(\sim 10 \$ /$ ton $)$ of these natural minerals makes the proposed integration an attractive technology for large-scale storage of solar energy and highly

Notation

\begin{tabular}{|c|c|c|c|}
\hline$c_{p, i}$ & Specific heat, $\mathrm{kJ} /(\mathrm{kmol} \cdot \mathrm{K})$ & $P_{\text {out }, \text { turb }}$ & outlet turbine pressure, bar \\
\hline$d T_{-} \min \_H E$ & Minimum temperature approach, ${ }^{\circ} \mathrm{C}$ & $y_{e q}$ & $\begin{array}{l}\text { equilibrium fraction of } \mathrm{CO}_{2} \text { in the } \\
\text { carbonator }\end{array}$ \\
\hline$F_{i}$ & molar flow rate of component $\mathrm{i}, \mathrm{kmol} / \mathrm{s}$ & $T$ & Temperature, $\mathrm{K}$ \\
\hline $\mathrm{F}_{\mathrm{CaCO}_{3}}$ & molar flow rate of $\mathrm{CaCO}_{3}$ & $T_{\text {carb }}$ & Carbonator temperature, $\mathrm{K}$ \\
\hline$F_{\mathrm{CaCO}, \mathrm{Carb}}$ & $\begin{array}{l}\text { molar flow rate of } \mathrm{CaCO}_{3} \text { (carbonator } \\
\text { side) }\end{array}$ & $T_{i n, \mathrm{CO} 2}$ & $\mathrm{CO}_{2}$ temperature at carbonator inlet, $\stackrel{\circ}{ } \mathrm{C}$ \\
\hline$F_{\mathrm{CaCO}, \mathrm{clc}}$ & $\begin{array}{l}\text { molar flow rate of } \mathrm{CaCO}_{3} \text { (calciner } \\
\text { side) }\end{array}$ & $T_{i n, \mathrm{CaO}}$ & $\mathrm{CaO}$ temperature at carbonator inlet, ${ }^{\circ} \mathrm{C}$ \\
\hline$F_{C a O, c r b}$ & $\begin{array}{l}\text { molar flow rate of } \mathrm{CaO} \text { (carbonator } \\
\text { side) }\end{array}$ & $T_{\text {reheat }}$ & Reheat temperature (Rankine cycle), ${ }^{\circ} \mathrm{C}$ \\
\hline$F_{C a O, c l c}$ & molar flow rate of regenerated sorbent & $T_{v v}$ & Live steam temperature, ${ }^{\circ} \mathrm{C}$ \\
\hline$F_{\text {CaO,unr,carb }}$ & $\begin{array}{l}\text { molar flow rate of unreacted } \mathrm{CaO} \\
\text { (carbonator side) }\end{array}$ & $W_{\text {comp }, 1}$ & compressor 1 power, $\mathrm{sCO}_{2}, \mathrm{MW}$ \\
\hline$F_{\text {CaO,unr,clc }}$ & $\begin{array}{l}\text { molar flow rate of unreacted } \mathrm{CaO} \\
\text { (calciner side) }\end{array}$ & $W_{\text {comp }, 2}$ & compressor 2 power, $\mathrm{sCO}_{2}, \mathrm{MW}$ \\
\hline \multirow[t]{2}{*}{$F_{\mathrm{CO}_{2}, \mathrm{clc}, \text { out }}$} & $\begin{array}{c}\text { molar flow rate of } \mathrm{CO}_{2} \text { at calciner } \\
\text { outlet }\end{array}$ & $W_{\text {turb }}$ & turbine power, $\mathrm{sCO}_{2}, \mathrm{MW}$ \\
\hline & & $\dot{W}$ & mechanical power, $\mathrm{kW}$ \\
\hline$F_{R, c a r b}$ & $\begin{array}{l}\text { recirculating molar flow rate } \\
\text { (carbonator side) }\end{array}$ & $X$ & $\mathrm{CaO}$ conversion $X$ \\
\hline$F_{R, c l c}$ & $\begin{array}{l}\text { recirculating molar flow rate (calciner } \\
\text { side) }\end{array}$ & $X_{s l p}$ & Split factor, $\mathrm{sCO}_{2}$ \\
\hline$h_{i}$ & Enthalpy, kJ/kmol & $\eta_{c}$ & isentropic compressor efficiency \\
\hline HXA & solid-solid heat exchanger & $\eta_{t}$ & isentropic turbine efficiency \\
\hline HXB & gas-solid heat exchanger & $\eta_{\text {integration }}$ & Global integration performance \\
\hline HXE & gas-solid heat exchanger & $\eta_{\text {storage }}$ & storage performance \\
\hline HXF & gas-solid heat exchanger & $\eta_{\text {cycle }}$ & power cycle performance \\
\hline HXI & gas-solid heat exchanger & $\eta_{c c}$ & Combined cycle performance \\
\hline HXG & gas-solid heat exchanger & $\phi_{\text {cycle }}$ & power cycle practicability \\
\hline$\dot{m}_{\mathrm{CO} 2, \mathrm{crb}}$ & $\mathrm{CO}_{2}$ mass flow rate through carbonator & $\Delta t_{\text {sun }}$ & average daytime period \\
\hline$\dot{m}_{\text {solids }}$ & solids mass flow rate, $\mathrm{kg} / \mathrm{s}$ & $\Delta H_{R}\left(T_{\text {react }}\right)$ & heat of reaction at the reactor temperature \\
\hline$P_{\text {carb }}$ & absolute carbonator pressure, bar & $\xi$ & extent of reaction per unit time \\
\hline
\end{tabular}




\begin{tabular}{|c|c|c|c|}
\hline$Q_{\text {input }}$ & thermal power input, $\mathrm{MW}$ & $\Phi$ & heat flux \\
\hline$P_{e q}$ & $\mathrm{CO}_{2}$ partial pressure at equilibrium, bar & $\Phi_{\text {carbonation }}$ & available heat of carbonation \\
\hline$P R$ & pressure ratio & $\varepsilon_{r e c}$ & recuperator efficiency, $\%$ \\
\hline$p_{\text {drop }}$ & pressure drops in $\mathrm{CO}_{2}$ circuit, bar & $\Delta P_{R, h o t}$ & pressure drop recuperator- hot side, $\%$ \\
\hline$P_{v v}$ & Live steam pressure, bar & $\Delta P_{R, \text { cold }}$ & pressure drop recuperator- coldside, $\%$ \\
\hline$y_{C O 2, \text { carb,in }}$ & $\begin{array}{c}\text { inlet molar fraction of } \mathrm{CO}_{2} \text { in the } \\
\text { carbonator }\end{array}$ & $\Delta P_{R, H E}$ & pressure drop heat exchanger- $\mathrm{SCO}_{2}, \%$ \\
\hline
\end{tabular}

\section{Acknowledgments}

650

651

652

653

654

655

656

657

658

659

660

661

662

663

664

665

666

667

668

669

670

671

672

673

674

675

676

677

678

679

680

681

682

683

684

685

686

687

This work was supported by the Spanish Government Agency Ministerio de Economia y Competitividad and FEDER Funds (contracts CTQ2014-52763-C2-1-R, CTQ2014- 52763-C22-R and MAT2013-41233-R).

\section{References}

[1] United Nations, United Nations. Framework Convention on Climate Change. Adoption of the Paris Agreement. vol. 21932. 2015.

[2] International Energy Agency. Technology Roadmap Solar Thermal Electricity 2014:52. doi:10.1007/SpringerReference_7300.

[3] Kuravi S, Trahan J, Goswami DY, Rahman MM, Stefanakos EK. Thermal energy storage technologies and systems for concentrating solar power plants. Prog Energy Combust Sci 2013;39:285-319. doi:10.1016/j.pecs.2013.02.001.

[4] Mahlia TMIMI, Saktisahdan TJJ, Jannifar A, Hasan MHH, Matseelar HSCSC. A review of available methods and development on energy storage; Technology update. Renew Sustain Energy Rev 2014;33:532-45. doi:10.1016/j.rser.2014.01.068.

[5] Medrano M, Gil A, Martorell I, Potau X, Cabeza LF. State of the art on high-temperature thermal energy storage for power generation. Part 2-Case studies. Renew Sustain Energy Rev 2010;14:56-72. doi:10.1016/j.rser.2009.07.036.

[6] Kearney D, Kelly B, Herrmann U, Cable R, Pacheco J, Mahoney R, et al. Engineering aspects of a molten salt heat transfer fluid in a trough solar field. Energy 2004;29:86170. doi:10.1016/S0360-5442(03)00191-9.

[7] Fernández AG, Ushak S, Galleguillos H, Pérez FJ. Development of new molten salts with $\mathrm{LiNO} 3$ and $\mathrm{Ca}(\mathrm{NO} 3) 2$ for energy storage in CSP plants. Appl Energy 2014;119:131-40. doi:10.1016/j.apenergy.2013.12.061.

[8] Zalba B, Marín JM, Cabeza LF, Mehling H. Review on thermal energy storage with phase change: materials, heat transfer analysis and applications. vol. 23. 2003. doi:10.1016/S1359-4311(02)00192-8.

[9] Pardo P, Deydier a., Anxionnaz-Minvielle Z, Rougé S, Cabassud M, Cognet P. A review on high temperature thermochemical heat energy storage. Renew Sustain Energy Rev 2014;32:591-610. doi:10.1016/j.rser.2013.12.014.

[10] Cot-Gores J, Castell A, Cabeza LF. Thermochemical energy storage and conversion: Astate-of-the-art review of the experimental research under practical conditions. Renew Sustain Energy Rev 2012;16:5207-24. doi:10.1016/j.rser.2012.04.007.

[11] Neveu P, Tescari S, Aussel D, Mazet N. Combined constructal and exergy optimization of thermochemical reactors for high temperature heat storage. Energy Convers Manag 2013;71:186-98. doi:10.1016/j.enconman.2013.03.035. 
[12] Janz GJ, Allen, Carolyn B, Bansal NP, Murphy RM, Tomkins RP. Physical Properties Data Compilations Relevant to Energy Storage. II. Molten Salts: Data on Single and Multi-Components Salt Systems. Natl Bur Stand 1979.

[13] N'Tsoukpoe KE, Liu H, Le Pierrès N, Luo L. A review on long-term sorption solar energy storage. Renew Sustain Energy Rev 2009;13:2385-96. doi:10.1016/j.rser.2009.05.008.

[14] Abedin A, Rosen M. A Critical Review of Thermochemical Energy Storage Systems. Open Renew Energy J n.d.:42-6. doi:10.2174/1876387101004010042.

[15] Sakellariou KG, Karagiannakis G, Criado YA, Konstandopoulos AG. Calcium oxide based materials for thermochemical heat storage in concentrated solar power plants. Sol Energy 2015;122:215-30. doi:10.1016/j.solener.2015.08.011.

[16] Rodriguez N, Alonso M, Grasa G, Abanades JC. Heat requirements in a calciner of $\mathrm{CaCO} 3$ integrated in a CO2 capture system using $\mathrm{CaO}$. Chem Eng J 2008;138:148-54. doi:10.1016/j.cej.2007.06.005.

[17] Valverde JM, Medina S. Reduction of Calcination Temperature in the Calcium Looping Process for $\mathrm{CO}_{2}$ Capture by Using Helium: In Situ XRD Analysis. ACS Sustain Chem Eng 2016:acssuschemeng.6b01966. doi:10.1021/acssuschemeng.6b01966.

[18] Romeo LM, Lara Y, Lisbona P, Martínez A. Economical assessment of competitive enhanced limestones for $\mathrm{CO} 2$ capture cycles in power plants. Fuel Process Technol 2009;90:803-11. doi:10.1016/j.fuproc.2009.03.014.

[19] Perejon A, Romeo LM, Lara Y, Lisbona P, Valverde JM. The Calcium-Looping technology for $\mathrm{CO} 2$ capture: On the important roles of energy integration and sorbent behavior. Appl Energy 2015;162:787-807. doi:10.1016/j.apenergy.2015.10.121.

[20] Sanchez-Jimenez PE, Valverde JM, Perez-Maqueda L. Multicyclic conversion of limestone at Ca-looping conditions: The role of solid-sate diffusion controlled carbonation. Fuel 2014;127:131-40. doi:10.1016/j.fuel.2013.09.064.

[21] Sarrion B, Valverde JM, Perejon A, Perez-maqueda LA, Sanchez-jimenez PE. On the multicycle activity of natural limestone/dolomite for cheap, efficient and non-toxic Thermochemical Energy Storage of Concentrated Solar Power. Energy Technol 2016. doi:10.1002/ente.201600068.

[22] Berger EE. Effect of Steam on the Decomposition of Limestone. Ind Eng Chem 1927;19:594-6. doi:10.1021/ie50209a026.

[23] Frangini S, Masi A. Molten carbonates for advanced and sustainable energy applications: Part I. Revisiting molten carbonate properties from a sustainable viewpoint. Int J Hydrogen Energy 2016;41:18739-46. doi:10.1016/j.ijhydene.2015.12.073.

[24] Fletcher EA, Moen RL. Hydrogen and oxygen from water. Science (80- ) 1977;197:1050-6.

[25] Zhang HL, Baeyens J, Degrève J, Cacères G. Concentrated solar power plants: Review and design methodology. Renew Sustain Energy Rev 2013;22:466-81. doi:10.1016/j.rser.2013.01.032.

[26] Siva Reddy V, Kaushik SC, Ranjan KR, Tyagi SK. State-of-the-art of solar thermal power plants - A review. Renew Sustain Energy Rev 2013;27:258-73. doi:10.1016/j.rser.2013.06.037.

[27] Yogi Goswami D. Solar Thermal Power Technology: Present Status and Ideas for the Future. Energy Sources 1998;20:137-45. doi:10.1080/00908319808970052.

[28] Liu M, Steven Tay NH, Bell S, Belusko M, Jacob R, Will G, et al. Review on concentrating solar power plants and new developments in high temperature thermal energy storage technologies. Renew Sustain Energy Rev 2016;53:1411-32. doi:10.1016/j.rser.2015.09.026.

[29] European Academies Scientific Advisory Council. Concentrating solar power: its 
[40] Grasa GS, Abanades JC. CO2 Capture Capacity of $\mathrm{CaO}$ in Long Series of Carbonation/Calcination Cycles. Ind Eng Chem Res 2006;45:8846-51. doi:10.1021/ie0606946.

[41] Romano MC. Modeling the carbonator of a Ca-looping process for $\mathrm{CO} 2$ capture from power plant flue gas. Chem Eng Sci 2012;69:257-69. doi:10.1016/j.ces.2011.10.041.

[42] Ortiz C, Chacartegui R, Valverde JM, Becerra JA. A new integration model of the calcium looping technology into coal fired power plants for $\mathrm{CO} 2$ capture. Appl Energy 2016;169:408-20. doi:10.1016/j.apenergy.2016.02.050.

[43] Diego ME, Arias B, Grasa G, Abanades JC. Design of a novel fluidized bed reactor to enhance sorbent performance in $\mathrm{CO} 2$ capture systems using $\mathrm{CaO}$. Ind Eng Chem Res 2014;53:10059-71. doi:10.1021/ie500630p.

[44] Valverde JM, Sanchez-Jimenez PE, Perez-Maqueda L. Ca-looping for postcombustion CO2 capture: A comparative analysis on the performances of dolomite and limestone. Appl Energy 2015;138:202-15. doi:10.1016/j.apenergy.2014.10.087.

[45] Sánchez D, Muñoz de Escalona JM, Chacartegui R, Muñoz A, Sánchez T. A comparison between molten carbonate fuel cells based hybrid systems using air and supercritical carbon dioxide Brayton cycles with state of the art technology. J Power Sources 2011;196:4347-54. doi:10.1016/j.jpowsour.2010.09.091.

[46] Sánchez D, Chacartegui R, Muñoz De Escalona JM, Muñoz A, Sánchez T. Performance analysis of a MCFC \& supercritical carbon dioxide hybrid cycle under part load operation. Int $\mathrm{J} \quad$ Hydrogen Energy 2011;36:10327-36. doi:10.1016/j.ijhydene.2010.09.072.

[47] Cheang VT, Hedderwick R a., McGregor C. Benchmarking supercritical carbon dioxide 
cycles against steam Rankine cycles for Concentrated Solar Power. Sol Energy 2015;113:199-211. doi:10.1016/j.solener.2014.12.016.

[48] Feher EG. The supercritical thermodynamic power cycle. Energy Convers 1968;8:8590. doi:10.1016/0013-7480(68)90105-8.

[49] Ahn Y, Bae SJ, Kim M, Cho SK, Baik S, Lee JI, et al. Review of supercritical CO2 power cycle technology and current status of research and development. Nucl Eng Technol 2015;47:647-61. doi:10.1016/j.net.2015.06.009.

[50] Chacartegui R, Muñoz De Escalona JM, Sánchez D, Monje B, Sánchez T. Alternative cycles based on carbon dioxide for central receiver solar power plants. Appl Therm Eng 2011;31:872-9. doi:10.1016/j.applthermaleng.2010.11.008.

[51] Iverson BD, Conboy TM, Pasch JJ, Kruizenga AM. Supercritical CO2 Brayton cycles for solar-thermal energy. Appl Energy 2013;111:957-70. doi:10.1016/j.apenergy.2013.06.020.

[52] Ma Z, Turchi CS. Advanced Supercritical Carbon Dioxide Power Cycle Configurations for Use in Concentrating Solar Power Systems. Supercrit CO 2 Power Cycle Symp 2011:1-4. doi:10.1115/GT2012-68932.

[53] Wright SA, Conboy TM, Rochau GE. High-Temperature Split-Flow Recompression Brayton Cycle Initial Test Results. Nucl Energy 2012.

[54] Moisseytsev A, Sienicki JJ. Investigation of alternative layouts for the supercritical carbon dioxide Brayton cycle for a sodium-cooled fast reactor. Nucl Eng Des 2009;239:1362-71. doi:10.1016/j.nucengdes.2009.03.017.

[55] Sabouhi H, Abbaspour A, Fotuhi-Firuzabad M, Dehghanian P. Reliability modeling and availability analysis of combined cycle power plants. Int J Electr Power Energy Syst 2016;79:108-19. doi:10.1016/j.ijepes.2016.01.007.

[56] Kelly Bruce, Ulf Herrmann MJH. ASME Forum 2001 Integrated Solar Combined Cycle System. Asme 2001.

[57] Alqahtani BJ, Patiño-Echeverri D. Integrated Solar Combined Cycle Power Plants: Paving the way for thermal solar. Appl Energy 2016;169:927-36. doi:10.1016/j.apenergy.2016.02.083.

[58] Okoroigwe E, Madhlopa A. An integrated combined cycle system driven by a solar tower: A review. Renew Sustain Energy Rev 2016;57:337-50. doi:10.1016/j.rser.2015.12.092.

[59] Li Y, Zhou L, Xu G, Fang Y, Zhao S, Yang Y. Thermodynamic analysis and optimization of a double reheat system in an ultra-supercritical power plant. Energy 2014;74:202-14. doi:10.1016/j.energy.2014.05.057.

[60] Manente G. High performance integrated solar combined cycles with minimum modifications to the combined cycle power plant design. Energy Convers Manag 2016;111:186-97. doi:10.1016/j.enconman.2015.12.079.

[61] Li Y, Yang Y. Thermodynamic analysis of a novel integrated solar combined cycle. Appl Energy 2014;122:133-42. doi:10.1016/j.apenergy.2014.02.017.

[62] Zare V, Hasanzadeh M. Energy and exergy analysis of a closed Brayton cycle-based combined cycle for solar power tower plants. Energy Convers Manag 2016;128:227-37. doi:10.1016/j.enconman.2016.09.080.

[63] Zarza E, Romero-Alvarez M. Concentrating Solar Thermal Power. Handb. Energy Effic. Renew. Energy, CRC Press; 2007, p. 21-98. doi:doi:10.1201/9781420003482.ch21.

[64] Siemens. Steam turbines for CSP plants. Siemens AG - Rep 2010:1-16.

[65] Rubin ES, Yeh S, Antes M, Berkenpas M, Davison J. Use of experience curves to estimate the future cost of power plants with $\mathrm{CO} 2$ capture. Int J Greenh Gas Control 2007;1:188-97. doi:10.1016/S1750-5836(07)00016-3.

[66] BAMMERT K, BOHNENKAMP W, REHWINKEL H. Results of acceptance tests on 
the blast furnace gas and oil fired Gelsenkirchen gas turbine. Stahl Und Eisen 1971;91.

[67] Bentivoglio F, Tauveron N, Geffraye G, Gentner H. Validation of the CATHARE2 code against experimental data from Brayton-cycle plants. Nucl Eng Des 2008;238:3145-59. doi:10.1016/j.nucengdes.2007.12.026.

[68] Tan Y, Nookuea W, Li H, Thorin E, Yan J. Property impacts on Carbon Capture and Storage (CCS) processes: A review. Energy Convers Manag 2016;118:204-22. doi:10.1016/j.enconman.2016.03.079.

[69] Martynov SB, Daud NK, Mahgerefteh H, Brown S, Porter RTJ. Impact of stream impurities on compressor power requirements for $\mathrm{CO} 2$ pipeline transportation. Int $\mathbf{J}$ Greenh Gas Control 2016;54:652-61. doi:10.1016/j.ijggc.2016.08.010.

[70] Najjar YSH, Zaamout MS. Comparative performance of closed cycle gas turbine engine with heat recovery using different gases. Heat Recover Syst CHP 1992;12:489-95. doi:10.1016/0890-4332(92)90017-C.

[71] NETL. Cost and Performance Baseline for Fossil Energy Plants Volume 1 : Bituminous Coal and Natural Gas to Electricity. vol. 1. 2013.

[72] U.S. Energy Information Administration. Cost and Performance Characteristics of New Generating Technologies, Annual Energy Outlook 2016. 2016.

[73] U.S. Departement of Energy. 2014 SunShot Initiative Portfolio 2014:232.

[74] Moore J. Development of a High Efficiency Hot Gas Turbo-Expander and Low Cost Heat Exchangers for Optimized CSP SCO2 Operation. 2016.

[75] Mehos MS. Beyond LCOE: The Value of CSP with Thermal Energy Storage. Sunshot Program Summit 2016. U.S. Department of Energy. 2016.

[76] Gangwal S, Muto A. Demonstration of High-Temperature Calcium-Based Thermochemical Energy Storage System for Use with Concentrating Solar Power Facilities. Sunshot Program Summit 2016. U.S. Department of Energy. 2016. 